\title{
Optimizing bronchodilation in the prevention of COPD exacerbations
}

\author{
Marc Miravitlles ${ }^{{ }^{*}} \mathbb{D}$, Antonio Anzueto ${ }^{2}$ and José R. Jardim³
}

\begin{abstract}
The natural disease course of chronic obstructive pulmonary disease (COPD) is often punctuated by exacerbations: acute events of symptom worsening associated with significant morbidity and healthcare resource utilization; reduced quality of life; and increased risk of hospitalization and death. The Global Initiative for Chronic Obstructive Lung Disease (GOLD) recommend that patients at risk of exacerbations (GOLD Groups $C$ and D) receive a long-acting muscarinic antagonist (LAMA) or a long-acting $\beta_{2}$-agonist (LABA)/LAMA combination, respectively, as preferred initial treatments. The latter recommendation is based on recent trial evidence demonstrating the superior efficacy of a fixed-dose LABA/LAMA over an inhaled corticosteroid (ICS)/LABA in exacerbation prevention. ICS in combination with a LABA is also indicated for prevention of exacerbations, but the use of ICS is associated with an increased risk of adverse events such as pneumonia, and offers limited benefits beyond those provided by LABA or LAMA monotherapy. In this review, we examine evidence from a number of pivotal studies of LABAs and LAMAs, administered as monotherapy or as part of dual or triple combination therapy, with a specific focus on their effect on exacerbations. We also discuss a new proposed treatment paradigm for the management of COPD that takes into account this recent evidence and adopts a more cautious approach to the use of ICS. In alignment with GOLD 2017, we suggest that ICS should be reserved for patients with concomitant asthma or in whom exacerbations persist despite treatment with LABA/LAMA.
\end{abstract}

Keywords: Dual bronchodilation, ICS, LABA, LAMA, Treatment guidelines, Triple therapy

\section{Background}

The natural trajectory of chronic obstructive pulmonary disease (COPD) is punctuated by exacerbations, defined as an acute worsening of symptoms that results in additional therapy $[1,2]$. In many cases, exacerbations are triggered by respiratory tract infections (predominantly viral, but also bacterial) and environmental factors such as air pollution, yet in approximately one third of cases, the cause remains unknown [3].

COPD exacerbations have a marked negative effect on both the patient and underlying disease processes, and can result in hospitalization and readmission, an increased risk of death [4] and a significant reduction in health status $[5,6]$. Exacerbations are also associated with long-term decline in lung function and a high socioeconomic cost [7-10]. Thus, optimizing the prevention and management of COPD exacerbations is an important clinical issue.

\footnotetext{
* Correspondence: mmiravitlles@vhebron.net

${ }^{1}$ Pneumology Department, Hospital Universitari Vall d'Hebron. CIBER de

Enfermedades Respiratorias (CIBERES), Barcelona, Spain

Full list of author information is available at the end of the article
}

A key step towards meeting this goal is to identify patients at greatest risk of exacerbation. The 'frequent exacerbator' phenotype ( $\geq 2$ exacerbations/year) describes patients who are particularly susceptible to exacerbations, in contrast to infrequent exacerbators [11, 12]. The exacerbator phenotype, which remains relatively stable over time [12], has a complex pathophysiology and is prevalent across all disease severities, but is more common in patients with worse lung function [12].

The Global Initiative for Chronic Obstructive Lung Disease (GOLD) provides treatment recommendations for patients who are at high risk of exacerbation: a longacting muscarinic antagonist (LAMA) or a long-acting $\beta_{2}$-agonist (LABA)/LAMA combination are recommended as primary choice treatment for these patients. Although the GOLD strategy document was developed with an international audience in mind, some countries and regions (e.g. Spain, UK, South America, and Canada) follow guidance outlined in their own recommendations as well [13-16]. 
Inhaled corticosteroids (ICS) are recommended for patients at high risk of exacerbation with concomitant asthma, or who experience further exacerbations following initial bronchodilator treatment [2]. However, there is widespread evidence of inappropriate use of ICS in patients at low risk of exacerbation $[17,18]$. Considering the known risks associated with long-term ICS use, only patients carefully considered as suitable candidates should receive treatment with the appropriate ICS and associated dose, such that treatment benefit will outweigh any potential risk [19].

Strong evidence supports the favorable efficacy and safety profile of dual bronchodilators. Compared with bronchodilator monotherapy and ICS/LABA, LABA/ LAMAs improve lung function [20-29] and reduce exacerbation risk $[23,24,28,29]$. The safety profile of LABA/LAMA combinations is generally similar to that of placebo or individual monocomponents [22, 30-33]. However, LABA/LAMA use is still relatively limited and further experience with these agents is needed [34].

In this review, we will examine the efficacy of various COPD treatments in terms of exacerbation prevention, with particular focus on bronchodilators, and discuss a new proposed treatment paradigm for reducing exacerbation risk in patients with COPD.

\section{Efficacy Of Bronchodilators In Prevention Of Exacerbations \\ Non-pharmacological intervention}

Smoking cessation is the most effective initial strategy for reducing COPD disease progression, particularly exacerbation risk $[2,35]$. Smoking cessation significantly reduces the progressive decline in lung function [36], and substantially lowers the risk of mortality [37], however a significant number of COPD patients continue to smoke [38]. Although smoking cessation results in a reduced rate of decline in lung function, disease progression may persist [39].

Influenza vaccination can reduce serious illness and death in patients with COPD [40-43].

Furthermore, a significant reduction in exacerbation rate has also been observed with vaccination versus placebo [40]. Findings from a population-based study suggested that COPD patients, especially the elderly, had a decreased risk of ischemic heart disease when receiving the influenza vaccine over many years [44].

Pulmonary rehabilitation (PR) reduces hyperinflation by promoting lung deflation and better lung ventilation, which is linked to an improved health status and exercise capacity [45]. PR also provides benefits that extend beyond the initial training period, such as: improved survival; improved recovery following hospitalization for exacerbation; reduced perceived intensity of breathlessness; and reduced anxiety and depression [2, 46, 47]. PR programs can significantly reduce the frequency of exacerbations and hospitalization, and the proportion of patients classified as 'frequent exacerbator' [48]. Non-pharmacological interventions, such as surgical modes or bronchoscopic modes of lung volume reduction, are also associated with a reduction of exacerbation; however, these interventions are limited to a small number of patients [49].

Encouraging patients to increase their levels of daily activity is also recommended, due to the general beneficial effects of physical exercise [2] and the reported links between lower levels of physical activity in patients with COPD and an increased risk of hospitalization $[50,51]$ and readmission [52].

\section{Pharmacological interventions}

It must be recognized that many studies presented here were not designed to test for the relative efficacy of treatments in exacerbation prevention, making it difficult to draw conclusions on their effects in at-risk populations. However, the following studies were powered to test for differences in exacerbation rate, and recruited patients at high risk of exacerbation, thus, enriching study populations: POET (1 year) [53]; SPARK (64 weeks) [24]; FLAME (52 weeks) [29]; and INSPIRE (2 years) [54].

\section{Single bronchodilation versus placebo in the prevention of exacerbations}

The two main classes of bronchodilators are $\beta_{2}$-agonists and muscarinic receptor antagonists. Both classes of bronchodilators improve patients' ability to breathe by relaxing airway smooth muscle, thereby reducing respiratory muscle activity and dynamic hyperinflation, and improving ventilatory mechanics [55-57]. Exacerbations are mainly triggered by infections associated with small airway inflammation [3], however environmental conditions, such as pollution, may also initiate or amplify these events [2]. The mechanisms by which bronchodilators prevent exacerbations are unclear, yet are thought to include decreased hyperinflation and mechanical stress, decreased mucus production and enhanced mucociliary clearance, the improvement of symptom severity and fluctuation, and potential anti-inflammatory properties [58]. Compared with placebo, the use of tiotropium $18 \mu \mathrm{g}$ once daily (q.d.) was associated with sustained reductions in lung hyperinflation and inspiratory capacity both at rest and during exercise, contributing to improvements in exertional dyspnea and increased exercise endurance in patients with COPD [57]. Treatment with formoterol $12 \mu \mathrm{g}$ twice daily (b.i.d.) significantly enhanced mucus clearance compared with tiotropium $18 \mu \mathrm{g}$ q.d. in patients with mild-to-moderate COPD [59]. AUGMENT demonstrated that treatment with both formoterol $12 \mu \mathrm{g}$ b.i.d. and aclidinium $400 \mu$ g b.i.d. significantly improved 
dyspnea and health status compared with placebo in patients with moderate-to-severe COPD [60]. Compared with formoterol $12 \mu \mathrm{g}$ b.i.d., tiotropium $18 \mu \mathrm{g}$ q.d. demonstrated a superior anti-inflammatory activity profile, significantly reducing the production of superoxide and pro-inflammatory mediators in COPD patients [61].

Traditionally, much of the evidence for the efficacy of LAMAs in exacerbation prevention has come from studies with tiotropium. More recently, there have been similar findings with glycopyrronium, aclidinium and umeclidinium, as well as the LABAs salmeterol and indacaterol. Table 1 summarizes the findings from major trials of these agents with regards to exacerbation prevention, although it should be noted that exacerbations were studied as a secondary endpoint in the majority of cases.

Most of the 11 studies comparing tiotropium (5 or $10 \mu \mathrm{g}$ q.d., via the soft-mist inhaler, or $18 \mu \mathrm{g}$ q.d. via drypowder inhaler) with placebo reported significant beneficial effects on various exacerbation-related outcomes. In nine studies, the number of exacerbation events per patient per year was significantly lower with tiotropium than placebo [62-70]. Eight studies reported significant delays in the time to first exacerbation with tiotropium versus placebo [62-69], and in six studies the proportion of patients experiencing one or more exacerbations, and the number of exacerbation days per year, were significantly lower with tiotropium than with placebo [62, 64-70]. Only three studies reported significantly lower hospitalizations due to exacerbation (rates, events or proportions of patients) with tiotropium [62, 64, 70]. Glycopyrronium $(50 \mu \mathrm{g}$ q.d.) $[71,72]$, aclidinium $(200$ or $400 \mu \mathrm{g}$ b.i.d. [73, 74], umeclidinium $(62.5 \mu \mathrm{g}$ and $125 \mu \mathrm{g}$ q.d.) [22, 75], salmeterol (50 $\mu$ g b.i.d.) [76] and indacaterol (doses ranging from 150-600 $\mu$ g q.d.) [77-79] have demonstrated similar beneficial effects compared with placebo.

In two pivotal studies, GLOW1 (26 weeks) and GLOW2 (1 year), glycopyrronium (50 $\mu$ g q.d.) significantly prolonged time to first moderate-to-severe exacerbation versus placebo [71, 72]. In GLOW1, glycopyrronium also significantly reduced the risk of severe COPD exacerbations leading to hospitalization and the proportion of hospitalizations due to COPD exacerbations [71]. In GLOW2, glycopyrronium significantly reduced the rate of moderate-to-severe exacerbations and the number of exacerbations requiring treatment with systemic corticosteroids or antibiotics, versus placebo [72].

In ACCORD (12 weeks) and ATTAIN (24 weeks), aclidinium (200 or $400 \mu \mathrm{g}$ b.i.d.) significantly reduced the rate of exacerbations of any severity and numerically reduced rates of moderate or severe exacerbations per patient per year compared with placebo [73, 74]. Two 24-week studies examining the efficacy of umeclidinium demonstrated significant reductions in the risk of exacerbations versus placebo $[22,75]$.

\section{Comparison of the efficacy of single bronchodilators in the prevention of exacerbations}

Only a few head-to-head studies have examined the relative effects of different bronchodilators on exacerbation outcomes (Table 2).

The first study to specifically test the efficacy of a LABA versus a LAMA in exacerbation prevention was POET, a randomized, double-blind, double-dummy, parallel-group trial in patients with moderate-to-very-severe COPD and a history of exacerbations. Compared with salmeterol (50 $\mu$ g b.i.d.), tiotropium (18 $\mu$ g q.d.) delayed the time to first exacerbation and significantly reduced the risk of exacerbation (187 days versus 145 , respectively; hazard ratio [HR] $0.83 ; p<0.001)$. Tiotropium also significantly prolonged the time to first severe exacerbation (HR 0.72; $p<0.001)$ and reduced the annual rates of severe, and moderate or severe exacerbations versus salmeterol (rate ratios [RR], $0.73[p<0.001]$ and $0.89[p=0.002]$, respectively) [53]. Similar findings were reported in INVIGORATE, where tiotropium (18 $\mu$ g q.d.) significantly reduced annualized exacerbation rate versus indacaterol $(150 \mu \mathrm{g}$ q.d.) (0.73 versus $0.90 ; \mathrm{RR} 1.24 ; p<0.0001)$ [80].

To date, no direct head-to-head, LAMA versus LAMA studies have been performed. In GLOW2, open-label tiotropium (18 $\mu$ g q.d.) was included as a reference arm; however, the study was not designed nor powered to test for differences between the two active treatments. Compared with placebo, exacerbation risk was reduced with glycopyrronium (HR 0.66; $p=0.001$ ) and with tiotropium (HR 0.61; $p=0.001$ ), although no formal comparisons between the two treatments were made [72]. In SPARK, which studied the efficacy of indacaterol/glycopyrronium (IND/GLY 110/50 $\mu$ g q.d.) compared with glycopyrronium (50 $\mu$ g q.d.) and tiotropium (18 $\mu$ g q.d.) in patients with severe-to-very severe COPD and an exacerbation history, the rate of moderate or severe exacerbations was similar between glycopyrronium and tiotropium monotherapies (HR 1.03; $p=0.68)$ [24].

\section{Dual bronchodilation versus placebo in the prevention of exacerbations}

The mechanisms underlying interactions between LABAs and LAMAs have not been fully elucidated. However, $\beta_{2}$ agonists can amplify muscarinic antagonist-mediated smooth muscle relaxation by modulating cholinergic neurotransmission and decreasing acetylcholine release, and muscarinic antagonists can augment $\beta_{2}$-agonist-mediated bronchodilation by reducing the bronchoconstrictor effects of acetylcholine [81]. The complimentary mechanisms of action of LABAs and LAMAs elicit additive effects on lung function, and provide a rationale for combining the two agents to optimize bronchodilation. Mechanisms that most likely involve reduced airway 


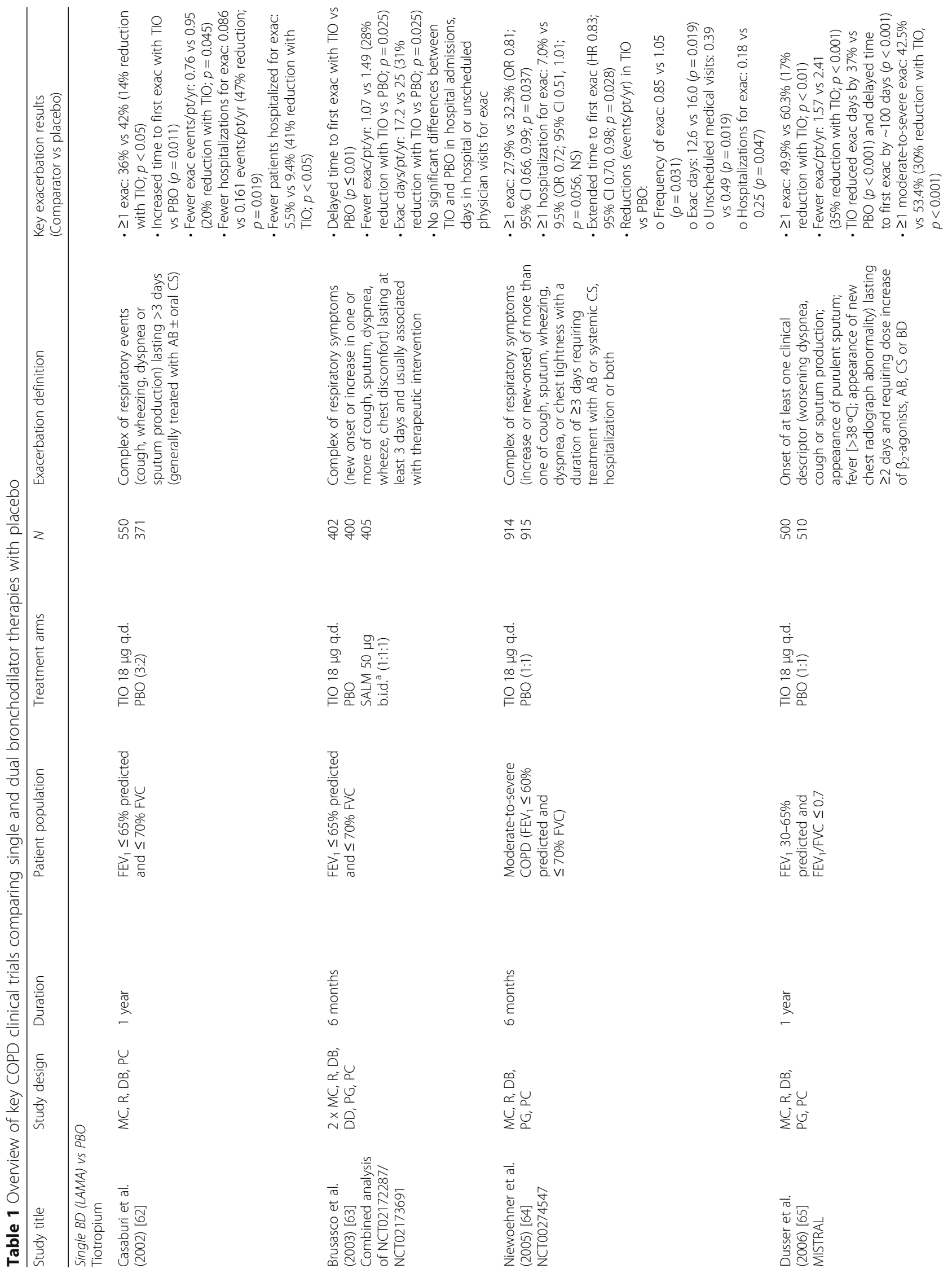




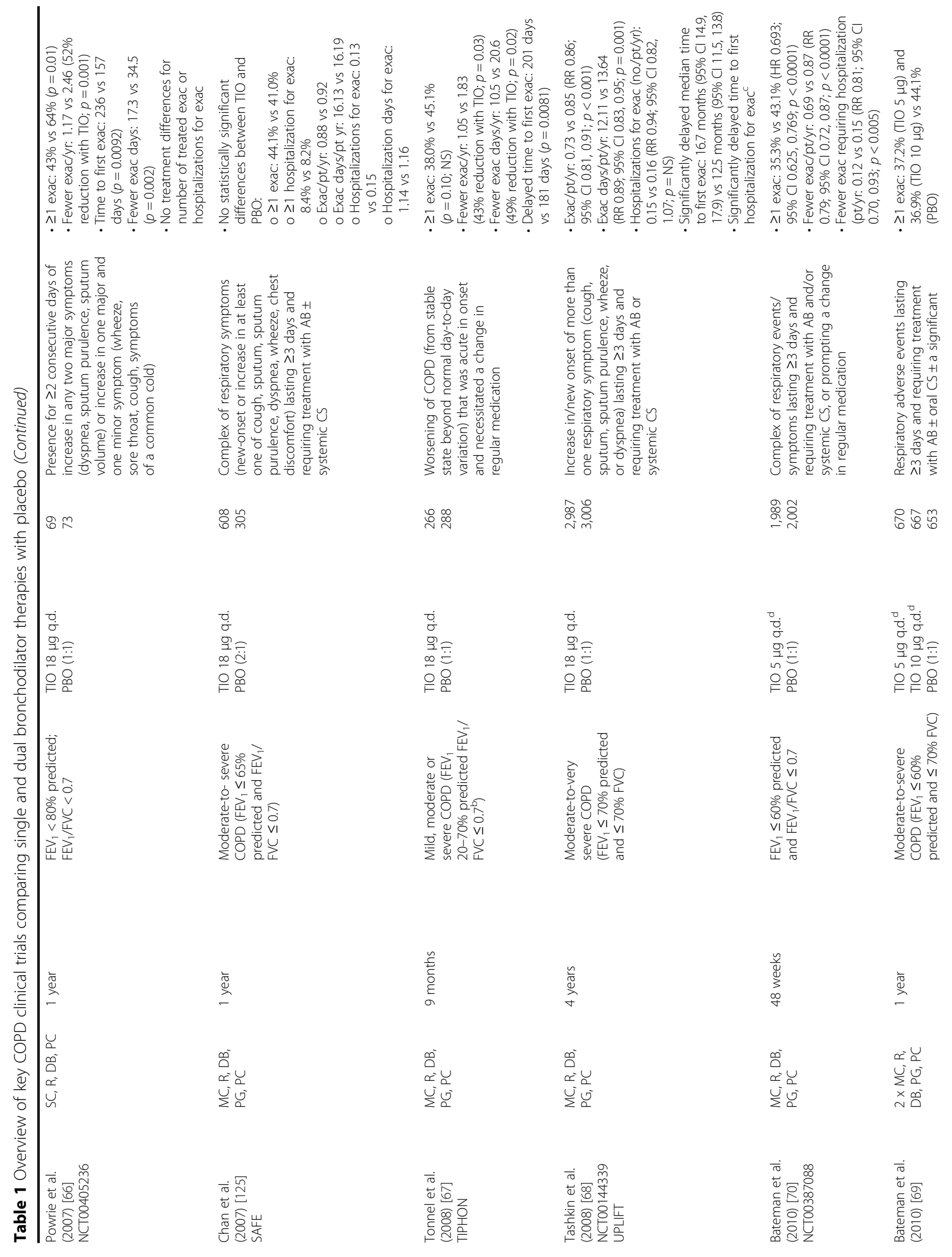




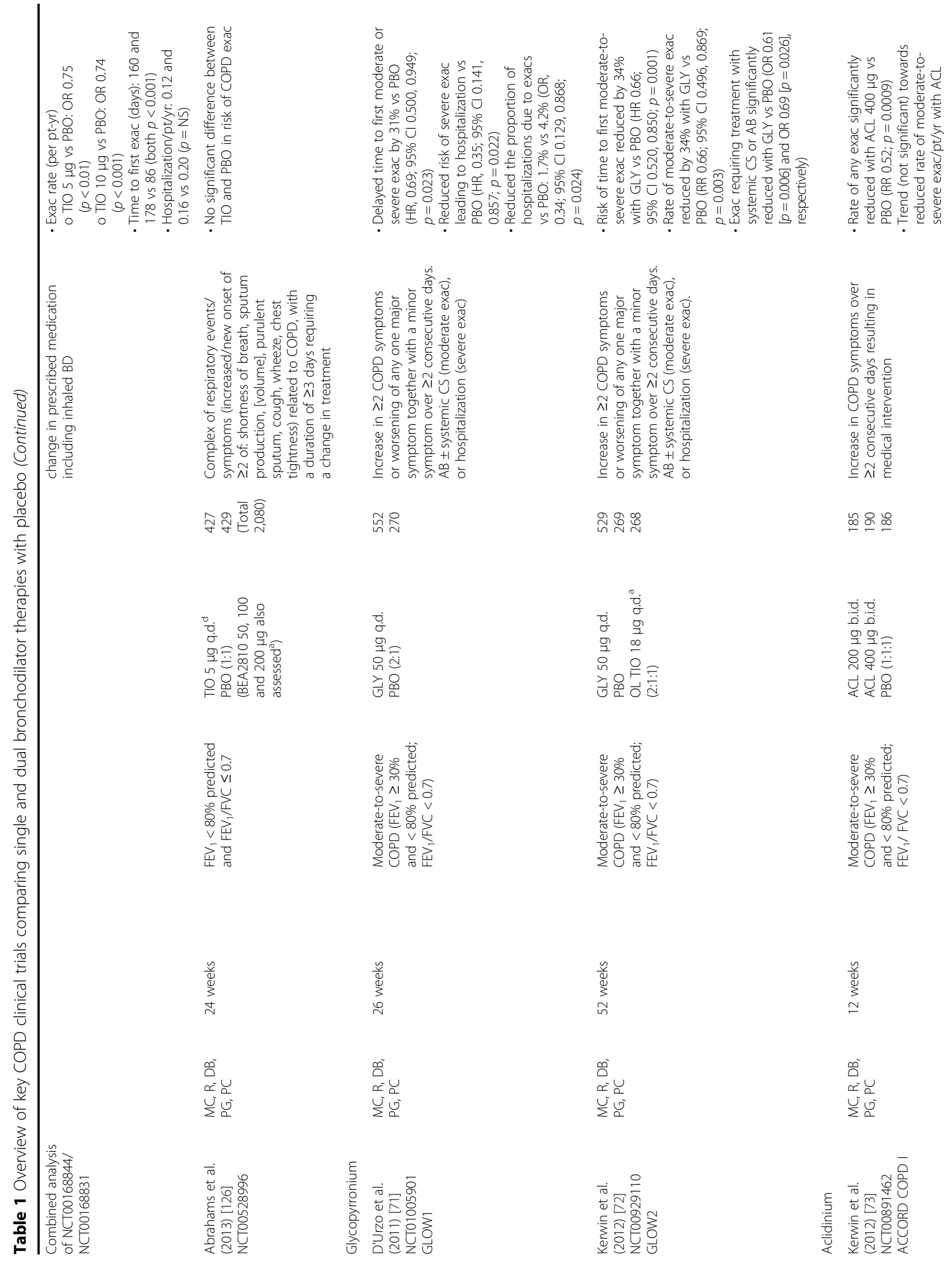




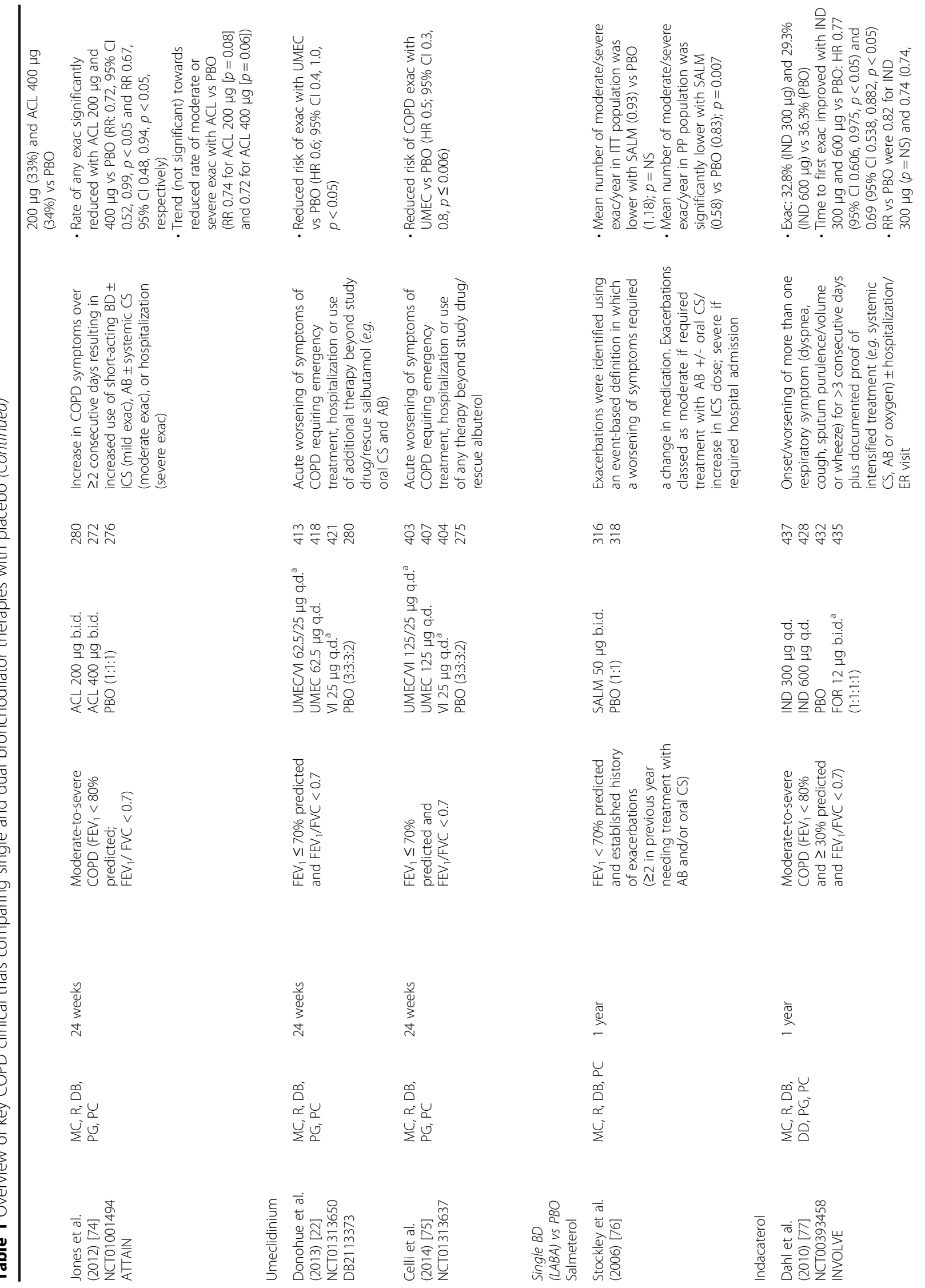




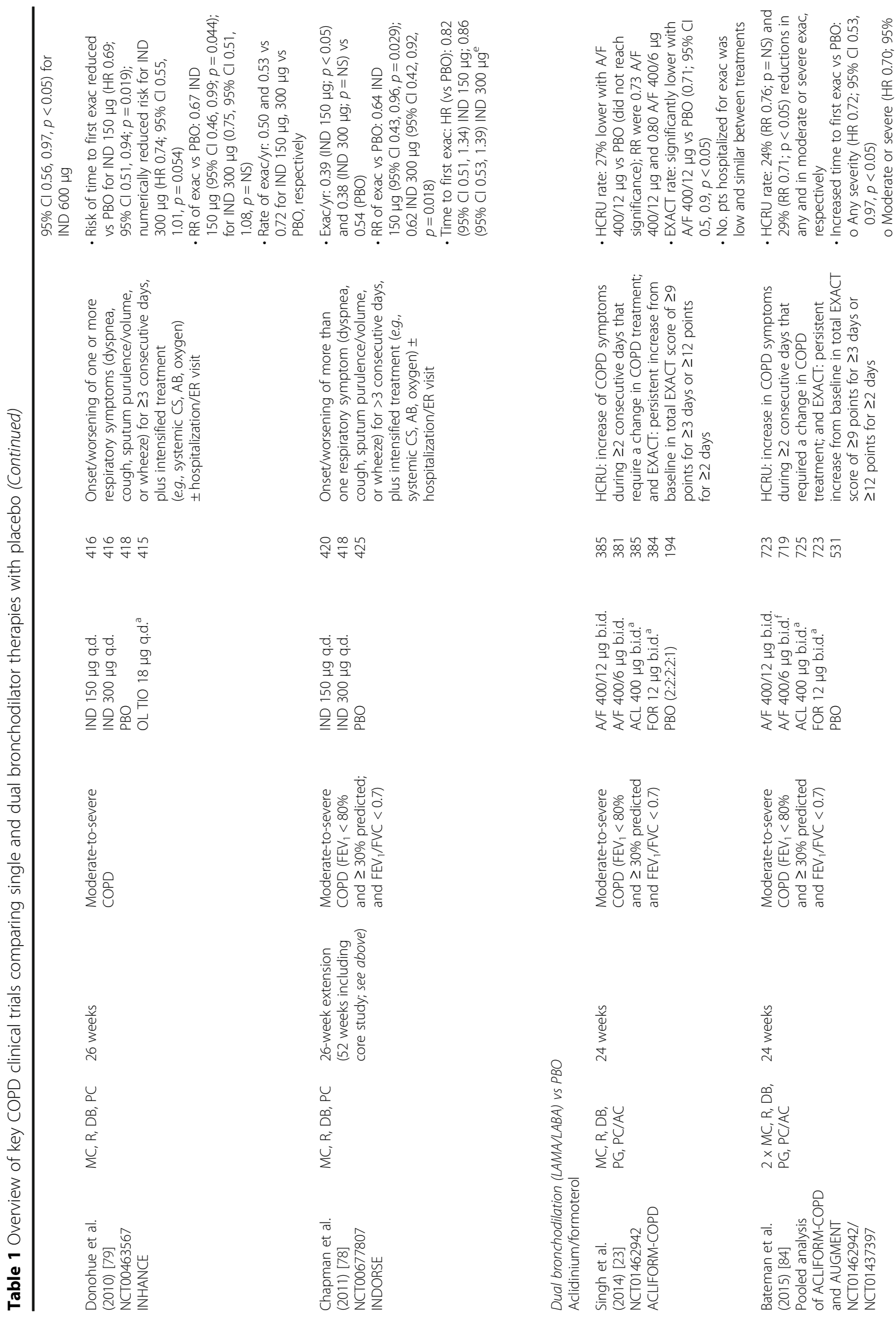




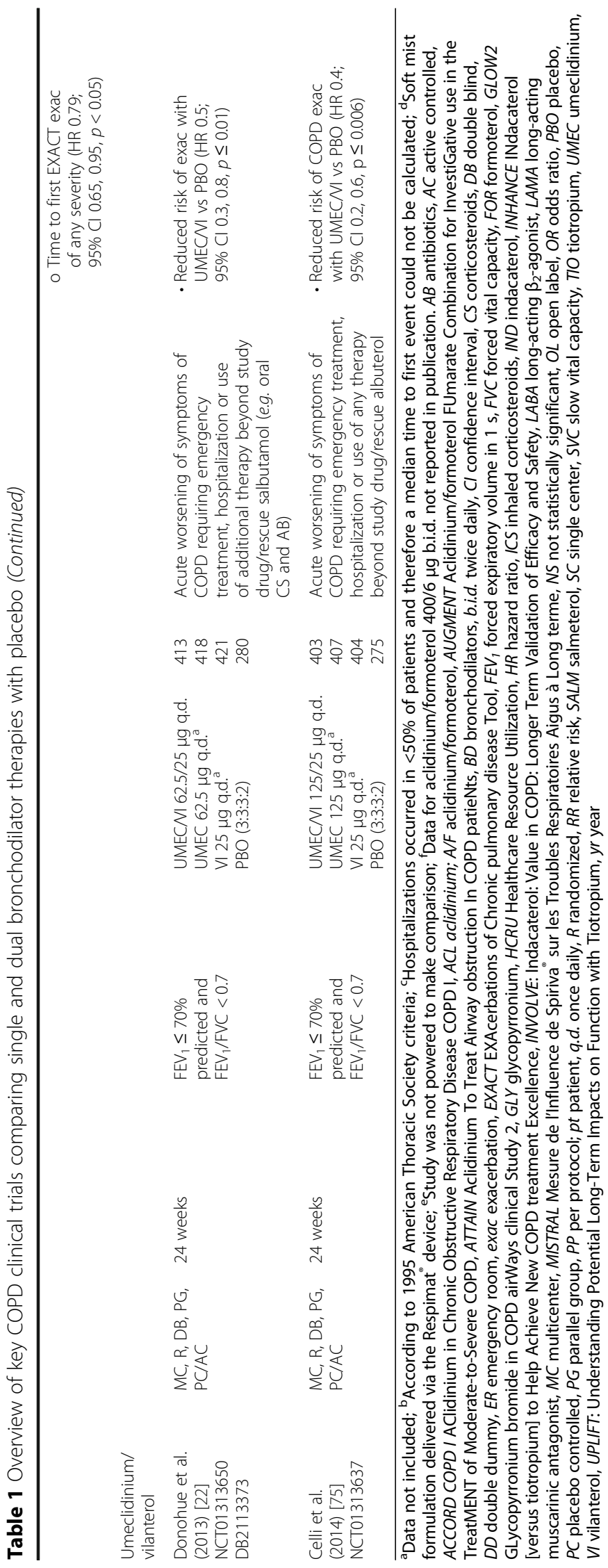




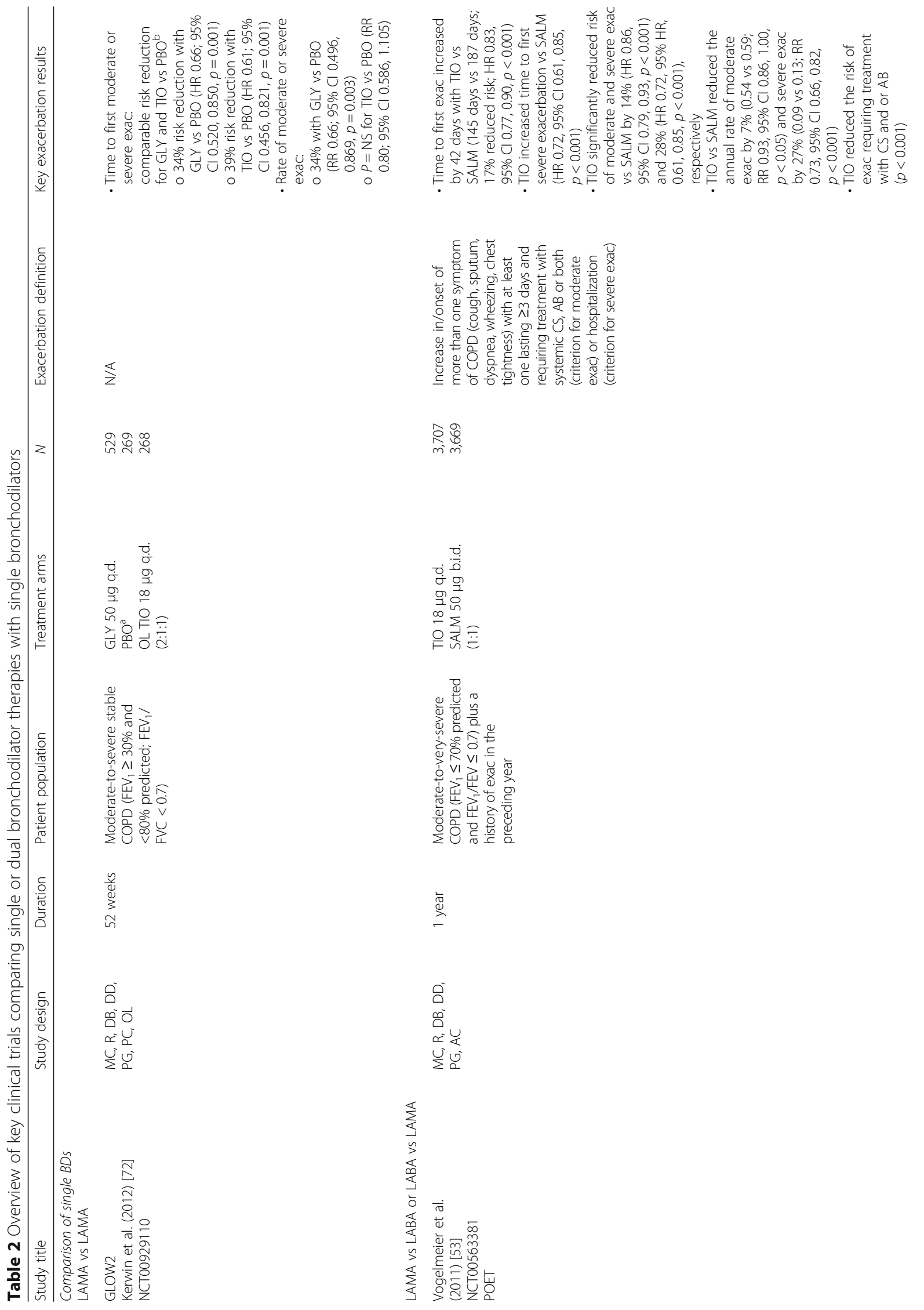




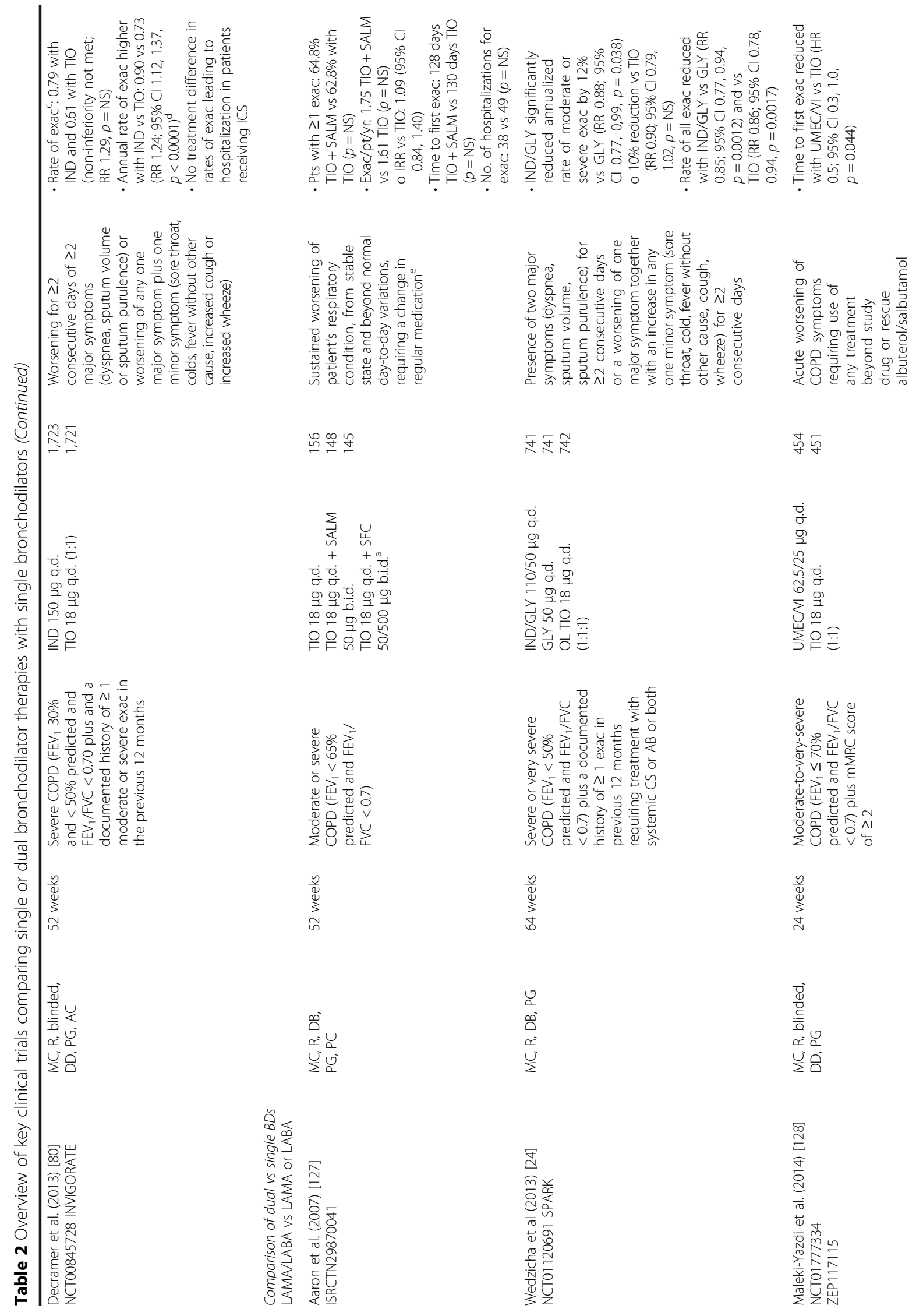




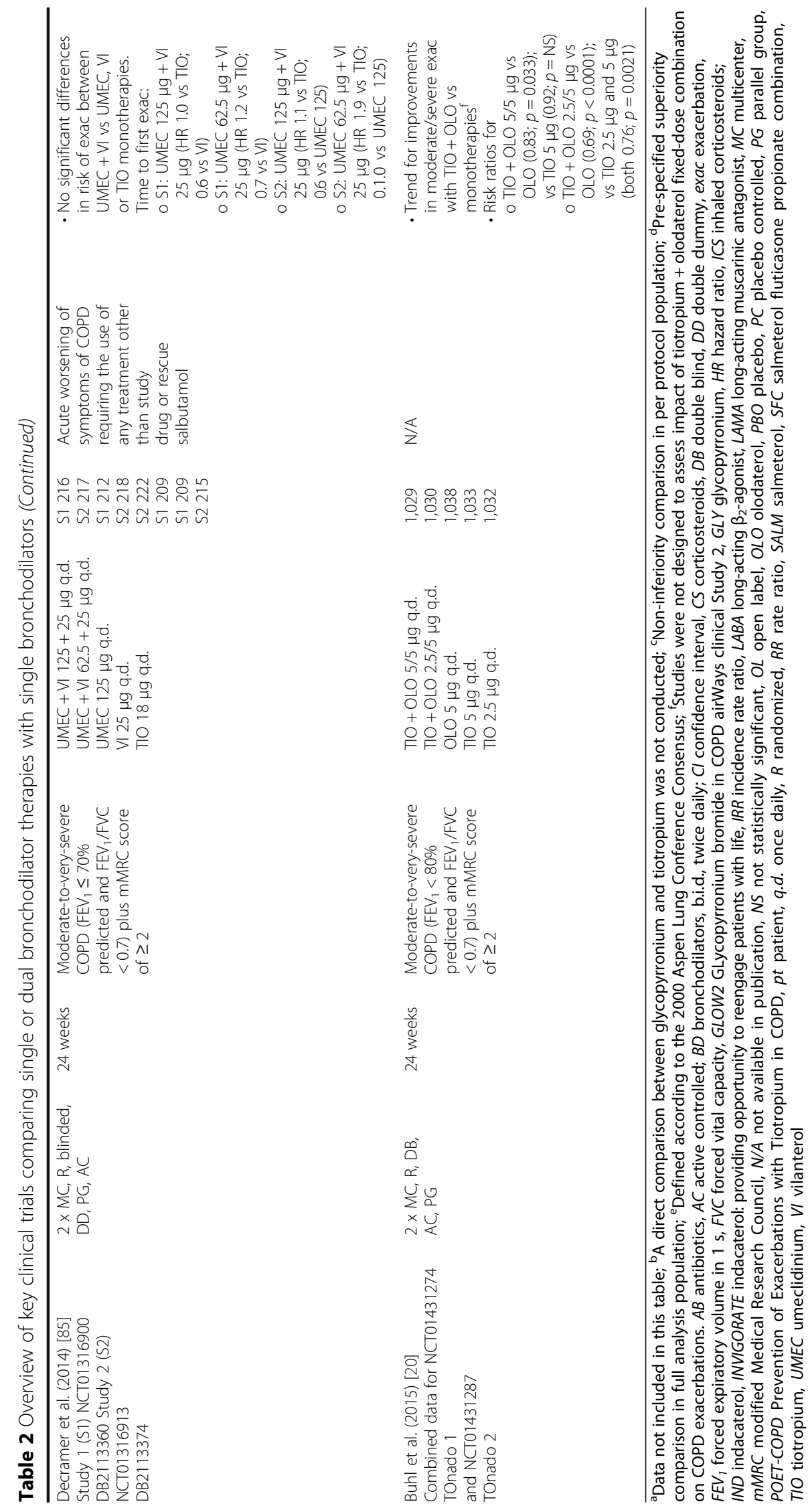


resistance, improved inspiratory capacity and reduced hyperinflation may confer benefits in terms of exacerbations [58].

Numerous dual bronchodilators have been developed with this aim in mind. They include once-daily IND/ GLY, umeclidinium/vilanterol (UMEC/VI) and tiotropium/olodaterol (TIO/OLO), and twice-daily aclidinium/formoterol (A/F) and glycopyrrolate/formoterol fumarate $(\mathrm{GLY} / \mathrm{F})$. In the USA, IND/GLY has been developed for twice-daily use [82]. Table 1 summarizes data from studies comparing the effects of dual bronchodilators on exacerbations with placebo.

Exacerbation risk was significantly reduced relative to placebo in UMEC/VI (62.5/25 and 125/25 $\mu$ g) studies $[22,75]$ whereas the effects of $\mathrm{A} / \mathrm{F}$ were less consistent across different doses (400/12 and 400/6 $\mu \mathrm{g}$ ) and exacerbation assessments [23, 83]. In a prespecified analysis of pooled data from ACLIFORM and AUGMENT, the higher dose of $\mathrm{A} / \mathrm{F}$ significantly reduced the rate of moderate or severe exacerbations compared with placebo, whether defined according to EXAcerbation of Chronic Pulmonary Disease Tool (EXACT) criteria (RR 0.78; $p<0.01$ ) [84] or healthcare resource utilization (HRU; RR $0.71 ; p<0.05)$ [83]. The higher-dose combination of $\mathrm{A} / \mathrm{F}$ also prolonged time to first exacerbation of any severity defined according to HRU (HR $0.72 ; p<0.05)$ or EXACT (HR $0.79 ; p<0.05)$ versus placebo ([83]. There are currently no published data comparing IND/GLY or TIO/OLO with placebo $[23,83]$.

\section{Dual versus single bronchodilation in the prevention of exacerbations}

As shown in Table 2, LABA/LAMAs can improve exacerbation outcomes compared with monotherapy, although not all studies were designed for this objective, and the results are variable. In SPARK, an exacerbation study, the annualized rate of moderate or severe exacerbations was significantly lower with IND/GLY versus glycopyrronium (primary endpoint, RR $0.88 ; p=0.038$ ), and rates of all exacerbations (mild, moderate or severe) were significantly lower with IND/GLY versus either glycopyrronium (RR $0.85 ; p=0.0012$ ) or tiotropium (RR $0.86 ; p=0.0017$ ) [24].

By contrast, in a 24-week study not designed for studying exacerbation prevention, UMEC/VI (125/25 $\mu \mathrm{g}$ q.d.) conferred no significant benefit for exacerbation risk compared with individual monotherapies or with tiotropium $(18 \mu \mathrm{g}$ q.d.) in patients with moderate-tovery severe COPD [85]. The results of the ongoing 52week DYNAGITO trial (NCT02296138), comparing the annualized rate of moderate-to-severe COPD exacerbations (primary endpoint) with TIO/OLO (5/5 $\mu$ g q.d.) versus tiotropium (5 $\mu$ g q.d.) in patients with severe-tovery severe COPD, will therefore be of interest [86].

\section{Single bronchodilation versus ICS/LABA combinations in the prevention of exacerbations}

Of the six ICS/LABA versus bronchodilator monotherapy studies, only two demonstrated significant benefits on exacerbations (Table 3) [87, 88]. It should be noted that these studies were not all designed to compare the effects of an ICS/LABA with single bronchodilation (but with placebo), and exacerbation endpoints were often secondary or exploratory.

One of the most robust studies was TORCH (3 years), which studied deaths (any cause) as the primary outcome, as well as exacerbation frequency between treatments. In TORCH, salmeterol/fluticasone propionate combination (SFC 50/500 $\mu$ g b.i.d.) significantly reduced the annual rate of moderate or severe exacerbations compared with salmeterol (50 $\mu$ g b.i.d.; RR 0.88; $p=0.002)$ [87].

In a pooled analysis of two 1-year trials, in which the primary endpoint was the yearly rate of moderate and severe exacerbations, fluticasone furoate/vilanterol (FF/ VI; $50 / 25 \mu \mathrm{g}, 100 / 25 \mu \mathrm{g}$ and $200 / 25 \mu \mathrm{g}$ q.d.) significantly reduced the rate of moderate or severe exacerbations compared with vilanterol (25 $\mu$ g q.d.; $p<0.05$ for all three doses) [88]. FF/VI (100/25 $\mu$ g and $200 / 25 \mu$ g q.d.) also significantly prolonged time to first moderate or severe exacerbation versus vilanterol monotherapy (HR $0.8 ; p=0.0365$ and HR 0.7; $p=0.0001$, respectively), and significantly reduced the number of exacerbations requiring systemic corticosteroids $(p<0.05$ and $p=0.0009$, respectively) [88].

In a post-factorial analysis of SUMMIT, FF/VI (100/25 $\mu \mathrm{g}$ q.d.) significantly reduced the rate of moderate or severe exacerbations versus fluticasone $(100 \mu \mathrm{g}$ q.d.; $p<0.001)$ and versus vilanterol (25 $\mu$ g q.d.; $p<0.001)$ [89].

Only INSPIRE has compared an ICS/LABA with LAMA monotherapy in exacerbation prevention [54]. No significant difference was observed between SFC (50/500 $\mu \mathrm{g}$ b.i.d.) and tiotropium (18 $\mu$ g q.d.) in HRU exacerbation rate (1.28 and 1.32, respectively) in this study [54].

\section{Dual bronchodilation versus ICS/LABA combinations in the prevention of exacerbations}

Exacerbation data are available from a number of studies comparing a LABA/LAMA with an ICS/LABA (Table 3). In a post-hoc analysis of ILLUMINATE (26 weeks), IND/GLY (110/50 $\mu$ g q.d.) significantly reduced the time to first exacerbation (HR $0.65 ; p=0.03$ ) versus SFC (50/500 $\mu$ g b.i.d.), in patients with moderate-to-severe COPD and no exacerbations in the previous year [90]. Likewise, in LANTERN (26 weeks), IND/GLY $(110 / 50 \mu \mathrm{g}$ q.d.) significantly reduced the rate of moderate or severe exacerbations (RR $0.69 ; p=0.048$ ) compared with SFC $(50 / 500 \mu \mathrm{g}$ b.i.d.), in patients with moderate-to-severe COPD and $\leq 1$ exacerbations in the previous year [28]. In a post-hoc analysis of 


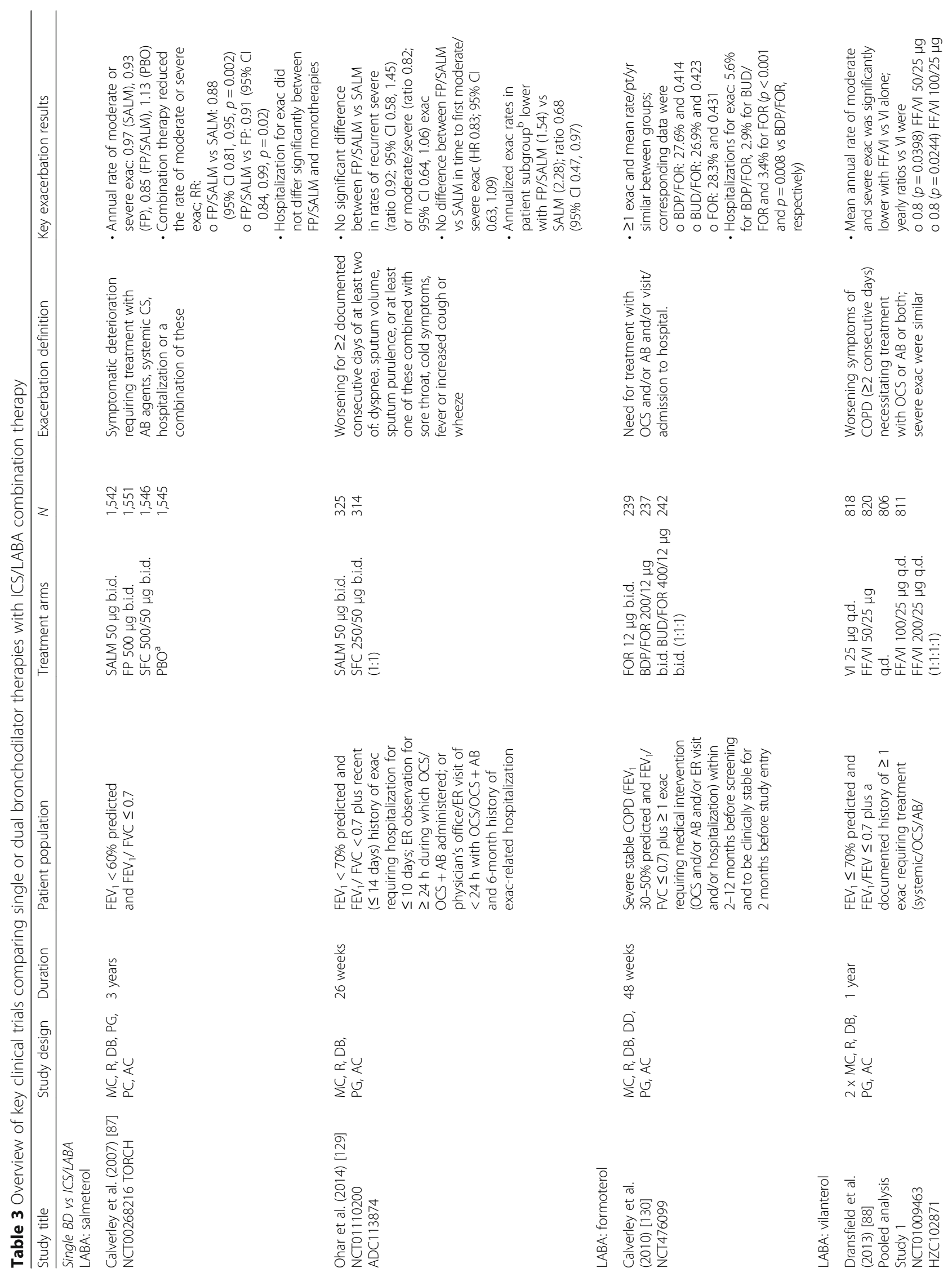




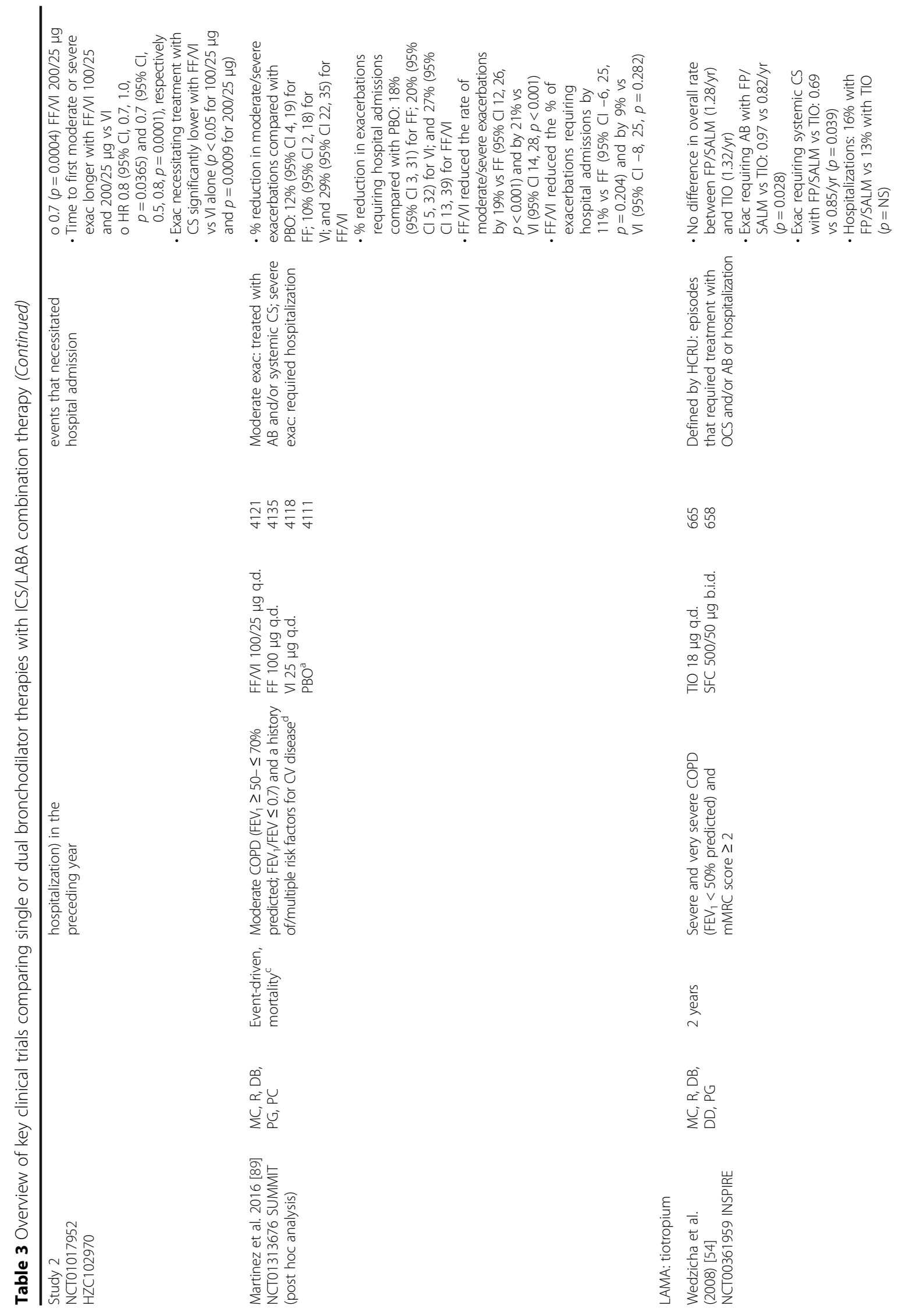




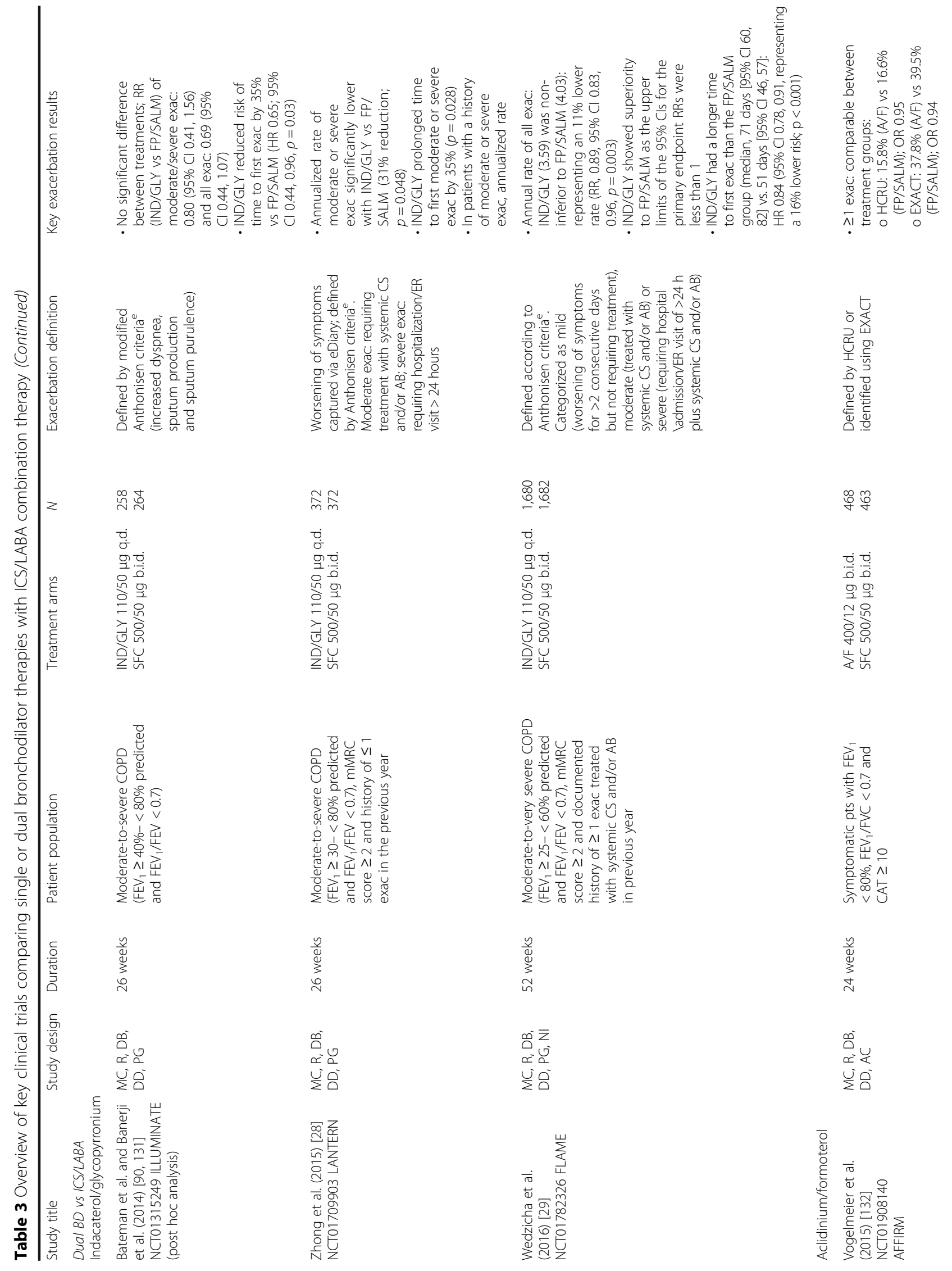




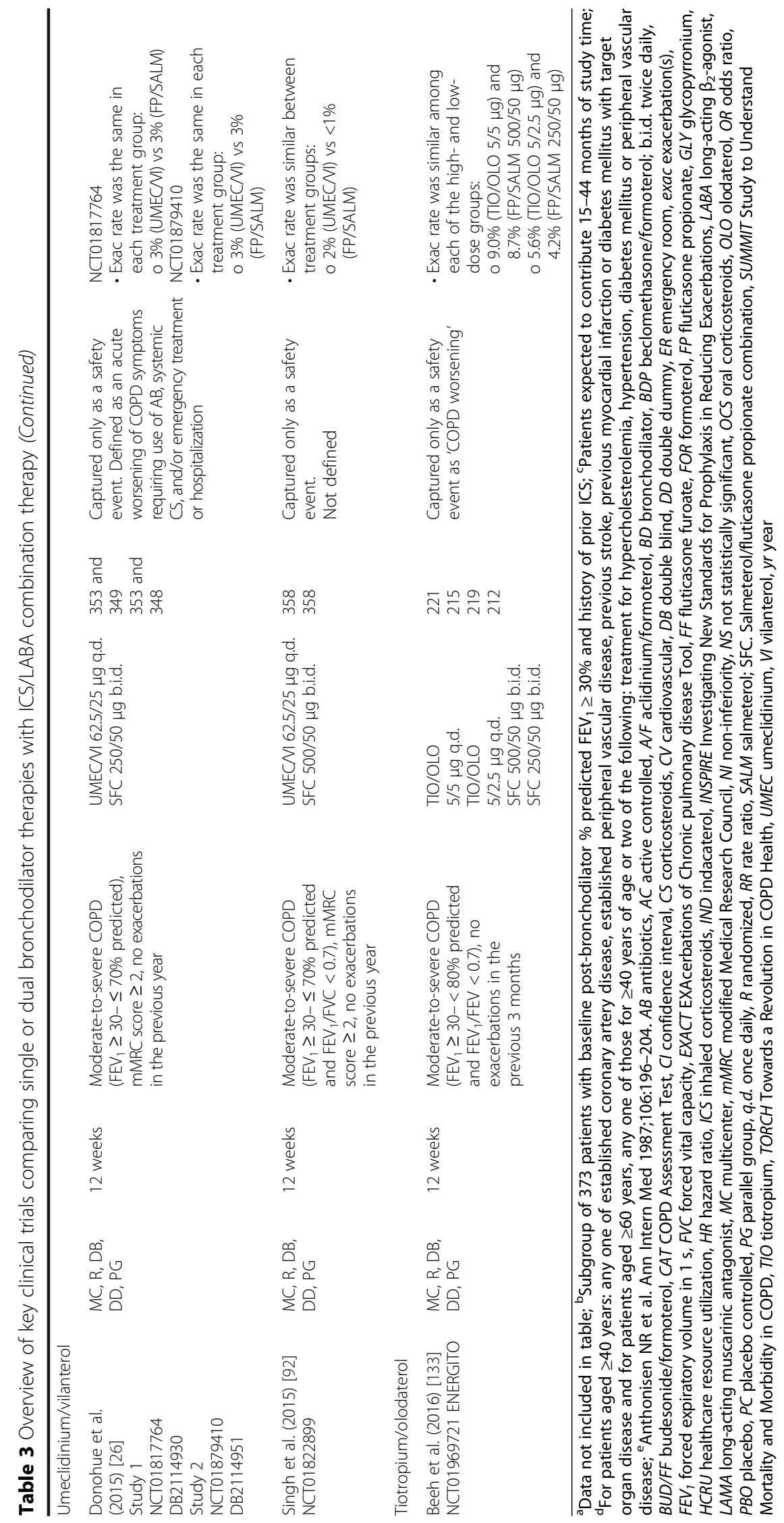


pooled data from LANTERN and ILLUMINATE, the annualized rate of moderate or severe exacerbations was significantly lower with IND/GLY versus SFC, in both the whole population $(p=0.02)$ and in subgroups of patients classified as either GOLD Group B ( $p=$ $0.16)$ or GOLD Group D ( $p=0.05$; patients were classified according to GOLD 2009 and 2010 for ILLUMINATE and LANTERN, respectively). Furthermore, IND/GLY delayed the time to first moderate or severe exacerbation compared with SFC in the overall population and in GOLD Group B and GOLD Group D subgroups [91].

The most recent study comparing a LABA/LAMA with an ICS/LABA was FLAME, which specifically studied the differences in exacerbations between IND/GLY $(110 / 50 \mu \mathrm{g}$ q.d) and SFC (50/500 $\mu$ g b.i.d.) as the primary outcome, and included an enriched patient population at high risk of exacerbation $(\geq 1$ exacerbation in the previous year) [29]. Compared with SFC, IND/GLY significantly reduced the rate of all COPD exacerbations ( $R R \quad 0.89 ; p=0.003$ ), and the rate of moderate or severe exacerbations (RR $0.83 ; p<0.001$ ). Additionally, IND/ GLY significantly prolonged the time to first exacerbation (HR 0.84; $p<0.001)$. The time to first moderate or severe exacerbation (HR 0.78; $p<0.001)$, and time to the first severe exacerbation (HR $0.81 ; p=0.046$ ) were also significantly prolonged with IND/GLY versus SFC. Treatment benefit or time to first exacerbation was detected as early as 4 weeks. Compared with SFC, IND/ GLY numerically, but not significantly, reduced the rate of exacerbations in patients with a history of $\geq 2$ exacerbations in the previous year, (19\% of the patient population). However, it is worth noting that this was a subgroup analysis and FLAME was not powered to detect treatment differences in subgroups [29].

In a 24-week trial comparing A/F (400/12 $\mu$ g b.i.d.) with SFC (50/500 $\mu$ g b.i.d), a similar proportion of patients experienced at least one exacerbation in the $\mathrm{A} / \mathrm{F}$ and SFC groups, regardless of exacerbation definition (HRU or EXACT criteria) [27]. However, the study was not designed to test exacerbations.

To date, there have been no long-term studies examining the effects of UMEC/VI or TIO/OLO on exacerbations in at-risk patients. Two 12-week studies comparing the efficacy of UMEC/VI (62/25 $\mu$ g q.d.) and SFC $(50 / 250 \mu \mathrm{g}$ b.i.d.) captured exacerbations as safety data and did not perform statistical testing [26, 88]. Likewise, in ENERGITO (a 12-week, randomized, double-blind, four-treatment, crossover study comparing the efficacy of TIO/OLO [5/5 $\mu$ g and 5/2.5 $\mu$ g q.d.] with SFC [50/500 $\mu \mathrm{g}$ and $50 / 250 \mu \mathrm{g}$ b.i.d.]), exacerbations were captured as safety data (reported as an adverse event of 'COPD worsening') [92]. Further long-term studies comparing UMEC/VI and TIO/OLO are required.
Triple therapy in the prevention of exacerbations

Evidence for the efficacy of triple therapy (ICS/LABA/ LAMA) in exacerbation prevention is currently limited. Nevertheless, in TRILOGY (1 year), the adjusted annual rate of moderate-to-severe exacerbations was significantly reduced following step-up to triple therapy (beclomethasone dipropionate/formoterol fumarate/glycopyrronium bromide [BDP/FF/GB] 100/6/12.5 $\mu \mathrm{g}$ two actuations b.i.d.) compared with continuing on $\mathrm{BDP} / \mathrm{FF}$ $100 / 6 \mu \mathrm{g}$ two actuations b.i.d. (0.41 versus 0.53 , respectively; RR 0.77; $p=0.005$ ) [93].

Similarly, TRINITY (1 year) compared the fixed-dose combination [FDC] of BDP/FF/GB (100/6/12.5 $\mu$ g b.i.d.) with a free combination of the same agents and LAMA monotherapy (tiotropium $18 \mu$ g q.d.) in patients with severe-to-very severe COPD. Compared with TIO, $\mathrm{BDP} / \mathrm{FF} / \mathrm{GB}$ FDC significantly reduced the rate of moderate/severe exacerbations ( 0.46 versus 0.57 , respectively; RR $0.80 ; p=0.0025)$. BDP/FF/GB and BDP/FF + TIO showed a similar effect on moderate/severe exacerbations (RR 1.01) [94]. Findings are eagerly anticipated from the ongoing InforMing the PAthway of COPD Treatment (IMPACT) study, comparing the rate of moderate and severe exacerbations between $\mathrm{FF} / \mathrm{UMEC} / \mathrm{VI}$ and FF/VI or UMEC/VI over 52-weeks in symptomatic COPD patients with an exacerbation in the previous 12 months [95].

\section{Other Pharmacological Treatments In The Prevention Of Exacerbations Mucolytics in the prevention of exacerbations}

Mucolytics are oral medicines designed to reduce mucus and sputum viscosity, thereby making it easier for patients to cough up mucus and clear it from the airways [96]. The current GOLD recommendations recognize that regular use of mucolytics may be beneficial in patients not receiving ICS, to reduce exacerbations and improve health status [2].

The antioxidant $\mathrm{N}$-acetylcysteine (NAC; $600 \mathrm{mg} /$ day), is recommended by the American College of Chest Physicians and Canadian Thoracic Society for patients with moderate-to-severe COPD and a history of two or more exacerbations in the previous 2 years [97]. However, NAC $600 \mathrm{mg} /$ day is currently not approved for use in the USA. In a 6-month study, the number of exacerbations was reduced by $41 \%$ with standard therapy plus NAC versus standard therapy alone, and fewer patients experienced at least one exacerbation (46 versus 63 patients, respectively) [98]. In PANTHEON (1 year), NAC (600 mg/b.i.d.) significantly reduced the annual rate of exacerbations versus placebo (1.16 versus 1.49 exacerbations per patient-year; $p=0.0011$ ) [99]. By contrast, in BRONCUS (3 year), a randomized, placebocontrolled study, there was no difference between NAC $(600 \mathrm{mg} /$ day $)$ and placebo in the number of 
exacerbations per year (a primary outcome, [1.25 versus $1.29 ; p=0.85]$ ), although sub-group analyses suggested that NAC might have reduced exacerbation rate in patients not receiving ICS treatment [100]. In a 2015 meta-analysis of 13 studies $(\mathrm{N}=4155), \quad \mathrm{NAC}$ significantly reduced the relative risk of exacerbations in patients with COPD and/or chronic bronchitis. The authors concluded that a dose of $600 \mathrm{mg}$ b.i.d. should be used in patients who have both chronic bronchitis and COPD, whereas the standard $600 \mathrm{mg} /$ day dose should suffice for patients who have chronic bronchitis alone [101]. Accordingly, one study showed that NAC (600 mg b.i.d.) was more effective than placebo in reducing exacerbation risk and prolonging time to first exacerbation in high-risk patients (GOLD Groups C and D, according to the 2011 GOLD recommendations), but not low-risk patients [102].

Two studies have examined the effects of erdosteine on exacerbations. EQUALIFE, an 8-month, randomized, double-blind trial, demonstrated that patients taking erdosteine (300 mg b.i.d.) had significantly fewer exacerbations and spent fewer days in hospital than those on placebo [103]. More recently, Moretti et al demonstrated that 10 -day treatment with erdosteine $(900 \mathrm{mg} /$ day $)$ was associated with a $39 \%$ lower risk of exacerbations in the 2 months post-discharge and a significant delay in time to first exacerbation at post-discharge days $30(p=$ $0.009)$ and $60(p=0.075)$ compared with placebo, in patients hospitalized following acute exacerbation [104]. In a 6-month, randomized trial, a significantly higher proportion of patients experienced no exacerbations when treated with continuous carbocysteine lysine salt monohydrate (SCMC-Lys; 2.7 g q.d.) compared with placebo $(p<0.001)$ [105]. Similarly, in PEACE (1 year), the annualized rate of exacerbations was significantly lower with carbocysteine $(1500 \mathrm{mg} /$ day $)$ than with placebo, representing a $25 \%$ reduction in risk $(p=0.004)$ [106].

\section{Phosphodiesterase-4 inhibitors in the prevention of exacerbations}

Phosphodiesterase-4 (PDE-4) inhibitors can inactivate immune and inflammatory cells by blocking the metabolism of cyclic adenosine monophosphate (cAMP) [107]. GOLD recommends addition of the selective, long-acting PDE-4 inhibitor roflumilast to a ICS/LABA/LAMA in GOLD Group D patients who continue to experience exacerbations despite triple therapy, particularly patients with a forced expiratory volume in one second $\left(\mathrm{FEV}_{1}\right)$ $<50 \%$ predicted, chronic bronchitis, and $\geq 1$ hospitalization for an exacerbation in the previous year [2].

A meta-analysis of 13 studies suggested that roflumilast $(500 \mu \mathrm{g}$ q.d.) was more effective than placebo in reducing the rate of acute exacerbations $(p<0.001)$ [107]. In REACT, roflumilast (500 $\mu$ g q.d.) reduced the rate of moderate-to-severe exacerbations by $13.2 \%$ versus placebo in patients with severe COPD, chronic bronchitis and at risk of frequent and severe exacerbations, and receiving ICS/LABA treatment with or without tiotropium (Poisson regression analysis, $p=0.0529$ ) [108]. In a post-hoc analysis of RE(2)SPOND (52 weeks), roflumilast $(500 \mu$ g q.d.) significantly reduced the rate of moderate or severe exacerbations versus placebo in patients with severe-to-very severe COPD and chronic bronchitis, a history of $>3$ exacerbations and/or $\geq 1$ hospitalizations in the prior year [109]. Roflumilast is indicated as a maintenance treatment (added on to bronchodilator therapy) in adults with severe COPD associated with chronic bronchitis, and a history of frequent exacerbations [110].

\section{Macrolides in the prevention of exacerbations}

Macrolides are antibiotics with antimicrobial, antiinflammatory, and immunomodulating effects. GOLD 2017 recommends the addition of a macrolide to an ICS/LABA/LAMA regimen in GOLD Group D patients who are former smokers and continue to suffer exacerbations despite triple therapy [2]. In COPD, the best studied macrolide is azithromycin. COLUMBUS (1 year) demonstrated that exacerbation rate was significantly reduced with azithromycin (500 $\mathrm{mg}$ three times/week), compared with placebo (odds ratio $=0.58, p=0.001$ ), in patients with COPD who had received treatment for $\geq 3$ exacerbations in the previous year despite optimal inhalation therapy [111]. Similar findings were reported in a 1 -year, randomized, controlled trial in patients with COPD at risk for exacerbations, where azithromycin (250 mg q.d.) significantly delayed median time to first exacerbation (266 versus 174 days; $p<0.001$ ), and significantly reduced the frequency of exacerbations (1.48 versus $1.83 ; p=0.01$ ) versus placebo [112]. Similar results have been reported in other, smaller studies comparing erythromycin and placebo $[113,114]$.

\section{Appropriate use of ICS}

Much evidence supports the use of ICS in patients with persistent asthma, yet the role of ICS in preventing exacerbations of COPD is less clear $[19,115]$. Various methodological issues in trial design and/or statistical analysis affect results and make subsequent study interpretation difficult [116].

However, data are emerging to suggest that raised blood or sputum eosinophil levels could predict a positive response (i.e. a reduction in exacerbations) to ICS/ LABA versus LABA monotherapy, or predict any deleterious effects ICS withdrawal may have [117-121].

The potential association between this 'eosinophilic phenotype' and a positive response to ICS requires further investigation, as the effect has not been consistent 
across studies within the same analysis [118], and may only be present in patients with a history of $\geq 2$ exacerbations in addition to raised eosinophil levels [121]. Prospective analysis of FLAME (which excluded patients with a previous diagnosis of asthma and/or a blood eosinophil count $>600 / \mathrm{mm}^{3}$ ), demonstrated that IND/GLY was superior to SFC in reducing the rate of moderateto-severe exacerbations, regardless of baseline eosinophil levels [29]. Thus, further studies are needed before any recommendations can be made regarding the potential use of ICS in specific sub-populations.

\section{Proposed Treatment Paradigm}

Figure 1 shows a proposed treatment paradigm for exacerbation prevention based on the evidence presented and centered on optimal use of bronchodilation, which has previously been published [122-124].

\section{Conclusions}

Not only do COPD exacerbations negatively impact the underlying disease course, but they also have a detrimental effect on patients' lives, resulting in lung function decline, increased risk of mortality and poor health status. While there has been a tendency to recommend the use of ICS for patients at high risk of exacerbations, ICS are associated with a myriad of side effects such as pneumonia. However, (and as recognized in the updated GOLD strategy document) evidence is emerging that suggests there may be more appropriate treatment strategies for many at risk patients, including a LABA/ LAMA combination.

The proposed treatment paradigm for exacerbation prevention is centered on optimizing bronchodilation as an initial pharmacological step, first with a LAMA, and subsequently with a dual LABA/LAMA should symptoms

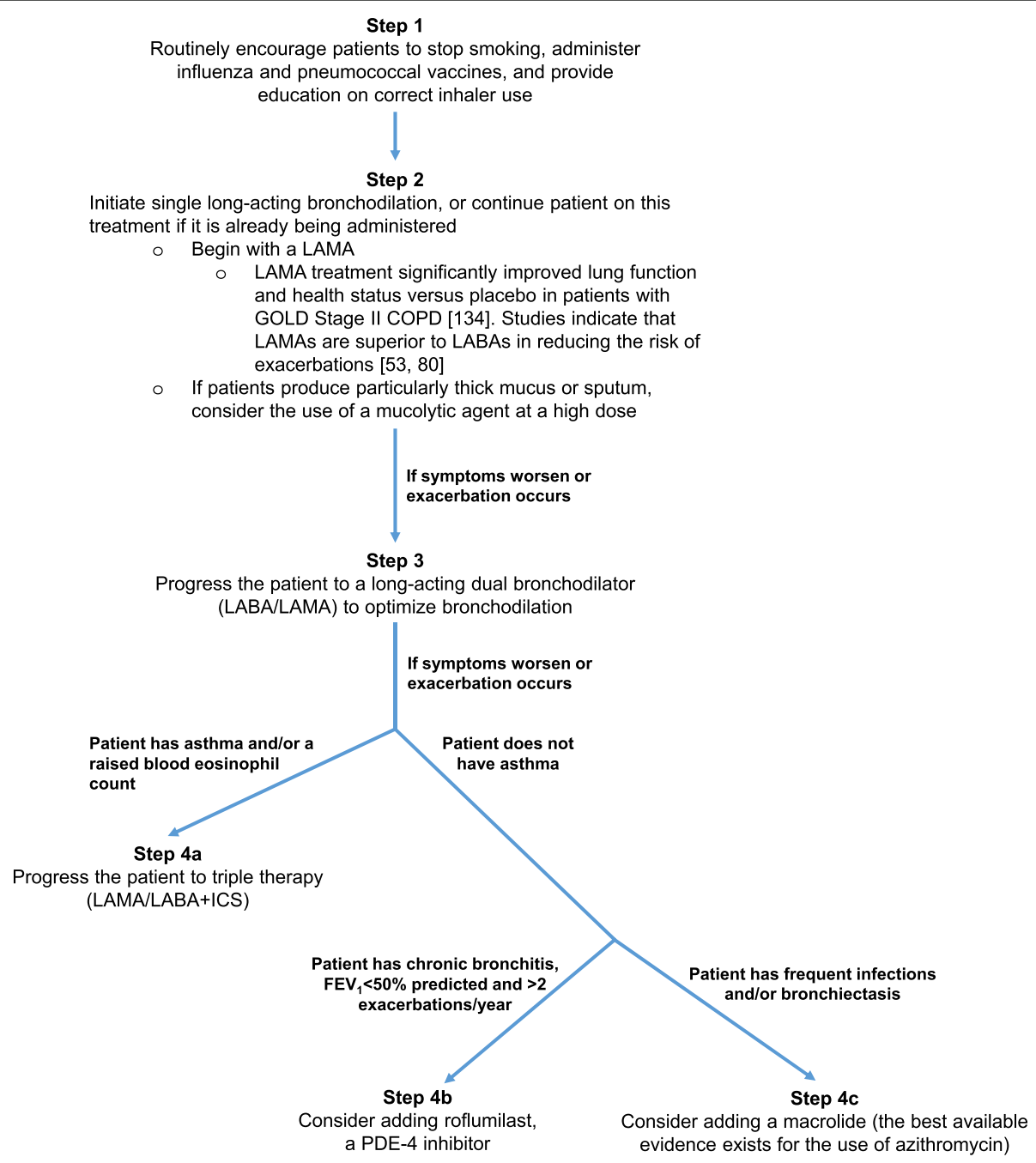

Fig. 1 A proposed treatment algorithm for the treatment of chronic obstructive pulmonary disease (COPD). FEV $\mathrm{V}_{1}$, forced expiratory volume in $1 \mathrm{~s}$; GOLD, Global Initiative for Chronic Obstructive Lung Disease; ICS, inhaled corticosteroids; LABA, long-acting $\beta_{2}$-agonist; LAMA, long-acting muscarinic antagonist; PDE-4, phosphodiesterase-4 [134] 
worsen or exacerbation occur. Only if patients continue to suffer exacerbations do we suggest the addition of an ICS or a PDE-4 inhibitor, depending on patient profile/phenotype. It is possible that a subgroup of patients with COPD who have raised blood or sputum eosinophils may respond better than others to ICS, although current data are still preliminary and somewhat contradictory. Future studies are warranted to better define the groups who may benefit from ICS, and to identify the mechanisms by which bronchodilation reduces exacerbations.

\begin{abstract}
Abbreviations
A/F: Aclidinium/formoterol; b.i.d.: Twice daily; BDP/FF/GB: Beclomethasone dipropionate/formoterol fumarate/glycopyrronium bromide; CAMP: Cyclic adenosine monophosphate; COPD: Chronic obstructive pulmonary disease; EXACT: EXAcerbations of Chronic obstructive pulmonary disease Tool; $\mathrm{FEV}_{1}$ : Forced expiratory volume in 1 second; FF/I: Fluticasone furoate/ vilanterol; GLY/F: Glycopyrronium/formoterol; GOLD: Global Initiative for Chronic Obstructive Lung Disease; HR: Hazard ratio; HRU: Healthcare resource utilization; ICS: Inhaled corticosteroids; IMPACT: InforMing the PAthway of COPD Treatment; IND/GLY: Indacaterol/Glycopyrronium; LABA: Long-acting $\beta_{2}$-agonist; LAMA: Long-acting muscarinic antagonist; NAC: N-acteylcysteine; OR: Odds ratio; PDE-4: Phosphodiesterase-4; PR: Pulmonary rehabilitation; q.d.: Once daily; RR: Rate ratio; SCMC-Lys: Carbocysteine lysine salt monohydrate; SFC: Salmeterol/Fluticasone propionate combination; TIO/OLO: Tiotropium/Olodaterol; UMEC/VI: Umeclidinium/Vilanterol
\end{abstract}

\section{Acknowledgements}

The authors were assisted in the preparation of the manuscript by David McMinn, a professional medical writer at CircleScience, an Ashfield company, part of UDG Healthcare plc.

\section{Funding}

Medical writing support was funded by Novartis Pharma AG (Basel, Switzerland).

\section{Availability of data and materials}

Not applicable.

\section{Authors' contributions}

Authors discussed and agreed to the scope of the manuscript and contributed to the development of the manuscript at all stages. All authors read and approved the final manuscript.

\section{Competing interests}

Marc Miravitlles has received speaker fees from Almirall, Boehringer Ingelheim, AstraZeneca, Chiesi, GlaxoSmithKline, Menarini, Teva, Grifols and Novartis, and consulting fees from Almirall, Bayer Schering, Boehringer Ingelheim, GlaxoSmithKline, Gebro Pharma, CLS Behring, Cipla, Medilmmune, Teva, Takeda, Novartis and Grifols.

Antonio Anzueto has received consultant fees from Boehringer Ingelheim, AstraZeneca, GlaxoSmithKline, and Novartis.

José R. Jardim has received speaker fees from, Boehringer Ingelheim, AstraZeneca, Chiesi, Teva, ACHE, Grifols, Zambon CLS Behring and Novartis, and consulting fees from Boehringer Ingelheim, Zambon, CLS Behring, Teva, EMS, ACHE, Novartis, Chiesi Farmoquimica and Grifols.

\section{Consent for publication}

Not applicable.

\section{Ethics approval and consent to participate} Not applicable.

\section{Publisher's Note}

Springer Nature remains neutral with regard to jurisdictional claims in published maps and institutional affiliations.

\section{Author details}

${ }^{1}$ Pneumology Department, Hospital Universitari Vall d'Hebron. CIBER de Enfermedades Respiratorias (CIBERES), Barcelona, Spain. ${ }^{2}$ University of Texas Health Science Center, and South Texas Veterans Health Care System, San Antonio, TX, USA. ${ }^{3}$ Respiratory Division, Escola Paulista de Medicina / Federal University de São Paulo, São Paulo, Brazil.

Received: 4 March 2017 Accepted: 29 May 2017

Published online: 20 June 2017

\section{References}

1. Wedzicha JA, Seemungal TA. COPD exacerbations: defining their cause and prevention. Lancet. 2007;370:786-6.

2. Vogelmeier CF, Criner GJ, Martínez FJ, Anzueto A, Barnes PJ, Bourbeau J, Celli BR, Chen R, Decramer M, Fabbri LM, Frith P, Halpin DM, López Varela MV, Nishimura M, Roche N, Rodríguez-Roisin R, Sin DD, Singh D, Stockley R, Vestbo J, Wedzicha JA, Agustí A. Global Strategy for the Diagnosis, Management, and Prevention of Chronic Obstructive Lung Disease 2017 Report: GOLD Executive Summary. Arch Bronconeumol. 2017;53:128-49.

3. Sapey E, Stockley RA. COPD exacerbations. 2: aetiology. Thorax. 2006;61:250-8.

4. Soler-Cataluña JJ, Martínez-García MA, Román Sánchez P, Salcedo E, Navarro M, Ochando R. Severe acute exacerbations and mortality in patients with chronic obstructive pulmonary disease. Thorax. 2005;60:925-31.

5. Seemungal TA, Donaldson GC, Paul EA, Bestall JC, Jeffries DJ, Wedzicha JA. Effect of exacerbation on quality of life in patients with chronic obstructive pulmonary disease. Am J Respir Crit Care Med. 1998;157:1418-22.

6. Miravitlles M, Ferrer M, Pont A, Zalacain R, Alvarez-Sala JL, Masa F, Verea H, Murio C, Ros F, Vidal R. Effect of exacerbations on quality of life in patients with chronic obstructive pulmonary disease: a 2 year follow up study. Thorax. 2004;59:387-95.

7. Celli BR, Thomas NE, Anderson JA, Ferguson GT, Jenkins CR, Jones PW, Vestbo J, Knobil K, Yates JC, Calverley PM. Effect of pharmacotherapy on rate of decline of lung function in chronic obstructive pulmonary disease: results from the TORCH study. Am J Respir Crit Care Med. 2008;178:332-8.

8. Donaldson GC, Seemungal TA, Bhowmik A, Wedzicha JA. Relationship between exacerbation frequency and lung function decline in chronic obstructive pulmonary disease. Thorax. 2002;57:847-52

9. Dhamane AD, Moretz C, Zhou Y, Burslem K, Saverno K, Jain G, Renda A, Kaila S. COPD exacerbation frequency and its association with health care resource utilization and costs. Int J Chron Obstruct Pulmon Dis. 2015;10:2609-18.

10. Miravitlles M, Murio C, Guerrero T, Gisbert R. Pharmacoeconomic evaluation of acute exacerbations of chronic bronchitis and COPD. Chest. 2002;121:1449-55.

11. Wedzicha JA, Brill SE, Allinson JP, Donaldson GC. Mechanisms and impact of the frequent exacerbator phenotype in chronic obstructive pulmonary disease. BMC Med. 2013;11:181

12. Hurst JR, Vestbo J, Anzueto A, Locantore N, Müllerova H, Tal-Singer R, Miller B, Lomas DA, Agusti A, MacNee W, et al. Susceptibility to exacerbation in chronic obstructive pulmonary disease. N Engl J Med. 2010;363:1128-38.

13. Miravitlles M, Soler-Cataluña JJ, Calle M, Molina J, Almagro P, Quintano JA, Trigueros JA, Cosío BG, Casanova C, Riesco JA, Simonet P, Rigau D, Soriano JB, Ancochea J. Spanish COPD guidelines (GesEPOC) 2017. Pharmacological treatment of stable chronic obstructive pulmonary disease. Arch Bronconeumol. 2017;53:324-35.

14. National Institute for Health and Care Excellence (NICE). Chronic obstructive pulmonary disease. Management of chronic obstructive pulmonary disease in adults in primary and secondary care. NICE clinical guideline 101 (partial update). Updated June 2010. Available at: https://www.nice.org.uk/ guidance/cg101. Accessed 5 June 2017.

15. Montes De Oca M, Lopez Varela MV, Acuna A, Schiavi E, Rey MA, Jardim J, Casas A, Tokumoto A, Torres Duque CA, Ramirez-Venegas A, et al. ALAT2014 Chronic Obstructive Pulmonary Disease (COPD) Clinical Practice Guidelines: questions and answers. Arch Bronconeumol. 2015;51:403-16.

16. O'Donnell DE, Hernandez P, Kaplan A, Aaron S, Bourbeau J, Marciniuk D, Balter M, Ford G, Gervais A, Lacasse Y, et al. Canadian Thoracic Society recommendations for management of chronic obstructive pulmonary disease - 2008 update - highlights for primary care. Can Respir J. 2008;15:1A-8A.

17. Price D, West D, Brusselle G, Gruffydd-Jones K, Jones R, Miravitlles M, Rossi A, Hutton C, Ashton VL, Stewart R, Bichel K. Management of COPD in the UK primary-care setting: an analysis of real-life prescribing patterns. Int J Chron Obstruct Pulmon Dis. 2014;9:889-905. 
18. Vestbo J, Vogelmeier C, Small M, Higgins V. Understanding the GOLD 2011 Strategy as applied to a real-world COPD population. Respir Med. 2014; 108:729-36.

19. Price D, Yawn B, Brusselle G, Rossi A. Risk-to-benefit ratio of inhaled corticosteroids in patients with COPD. Prim Care Respir J. 2013;22:92-100.

20. Buhl R, Maltais F, Abrahams R, Bjermer L, Derom E, Ferguson G, Fležar M Hébert J, McGarvey L, Pizzichini E, et al. Tiotropium and olodaterol fixeddose combination versus mono-components in COPD (GOLD 2-4). Eur Respir J. 2015;45:969-79

21. Bateman ED, Ferguson GT, Barnes N, Gallagher N, Green Y, Henley M, Banerji D. Dual bronchodilation with QVA149 versus single bronchodilator therapy: the SHINE study. Eur Respir J. 2013;42:1484-94.

22. Donohue JF, Maleki-Yazdi MR, Kilbride S, Mehta R, Kalberg C, Church A. Efficacy and safety of once-daily umeclidinium/vilanterol $62.5 / 25 \mathrm{mg}$ in COPD. Respir Med. 2013;107:1538-46.

23. Singh D, Jones PW, Bateman ED, Korn S, Serra C, Molins E, Caracta C, Gil EG, Leselbaum A. Efficacy and safety of aclidinium bromide/formoterol fumarate fixed-dose combinations compared with individual components and placebo in patients with COPD (ACLIFORM-COPD): a multicentre, randomised study. BMC Pulm Med. 2014;14:178.

24. Wedzicha JA, Decramer M, Ficker JH, Niewoehner DE, Sandstöm T, Taylor AF, D'Andrea P, Arrasate C, Chen H, Banerji D. Analysis of chronic obstructive pulmonary disease exacerbations with the dual bronchodilator QVA149 compared with glycopyrronium and tiotropium (SPARK): a randomised, double-blind, parallel-group study. Lancet Respir Med. 2013;1:199-209.

25. Vogelmeier CF, Bateman ED, Pallante J, Alagappan VK, D'Andrea P, Chen H, Banerji D. Efficacy and safety of once-daily QVA149 compared with twicedaily salmeterol-fluticasone in patients with chronic obstructive pulmonary disease (ILLUMINATE): a randomised, double-blind, parallel group study. Lancet Respir Med. 2013;1:51-60.

26. Donohue JF, Worsley S, Zhu CQ, Hardaker L, Church A. Improvements in lung function with umeclidinium/vilanterol versus fluticasone propionate/ salmeterol in patients with moderate-to-severe COPD and infrequent exacerbations. Respir Med. 2015;109:870-81.

27. Vogelmeier C, Paggiaro PL, Dorca J, Sliwinski P, Mallet M, Kirsten AM, Beier J, Seoane B, Segarra RM, Leselbaum A. Efficacy and safety of aclidinium/ formoterol versus salmeterol/fluticasone: a phase 3 COPD study. Eur Respir J. 2016:48:1030-9.

28. Zhong N, Wang C, Zhou X, Zhang N, Humphries M, Wang C, Thach C, Patalano F, Banerji D. LANTERN: a randomized study of QVA149 versus salmeterol/fluticasone combination in patients with COPD. Int J Chron Obstruct Pulmon Dis. 2015;10:1015-26.

29. Wedzicha JA, Banerji D, Chapman KR, Vestbo J, Roche N, Ayers RT, Thach C, Fogel R, Patalano F, Vogelmeier C. Indacaterol-glycopyrronium versus salmeterol-fluticasone for COPD. N Engl J Med. 2016;374:2222-34.

30. Welte T, Vogelmeier C, Dahl R, Chapman KR, Rudolf M, Mehta R, D'Andrea P, Chen H, Banerji D. Once-daily QVA149 has a good safety profile in patients with COPD. Eur Respir J. 2013;42 Suppl 57:143s-44s. Abstract P757.

31. Ferguson GT, Barnes N, Mehta R, D'Andrea P, Chen H, Banerji D. Cardio- and cerebro-vascular safety of QVA149: Results from a pooled analysis. Eur Respir J. 2013:42 Suppl 57:878s. Abstract P4139.

32. Korn S, Kerwin E, Donohue J, Shreshta P, Leselbaum A, Lei A. Safety of aclidinium bromide/formoterol fumarate fixed-dose combination in COPD: pooled analyses of three Phase III studies. Eur Respir J. 2014;44 Suppl 58: P2416. Abstract.

33. Buhl R, Abrahams R, Bjermer L, Derom E, Flezar M, Hebert J, Veale A, Groenke L, Hamilton A, Tetzlaff K, et al. Safety of once-daily tiotropium and olodaterol fixed-dose combination via the Respimat in chronic obstructive pulmonary disease in two 1-year studies. Eur Respir J. 2014;44 Suppl 59: P922. Abstract.

34. Barrecheguren M, Monteagudo M, Ferrer J, Borrell E, Llor C, Esquinas C, Miravitlles M. Treatment patterns in COPD patients newly diagnosed in primary care. A population-based study. Respir Med. 2016;111:47-53.

35. Au DH, Bryson CL, Chien JW, Sun H, Udris EM, Evans LE, Bradley KA. The effects of smoking cessation on the risk of chronic obstructive pulmonary disease exacerbations. J Gen Intern Med. 2009;24:457-63.

36. Petty TL. The history of COPD. Int J Chron Obstruct Pulmon Dis. 2006;1:3-14.

37. Anthonisen NR, Skeans MA, Wise RA, Manfreda J, Kanner RE, Connett JE, Lung Health Study Research $G$. The effects of a smoking cessation intervention on 14.5-year mortality: a randomized clinical trial. Ann Intern Med. 2005;142:233-9.
38. Vozoris NT, Stanbrook MB. Smoking prevalence, behaviours, and cessation among individuals with COPD or asthma. Respir Med. 2011;105:477-84.

39. Scanlon PD, Connett JE, Waller LA, Altose MD, Bailey WC, Buist AS, Tashkin DP. Lung Health Study Research G. Smoking cessation and lung function in mild-to-moderate chronic obstructive pulmonary disease. The Lung Health Study. Am J Respir Crit Care Med. 2000;161:381-90.

40. Poole PJ, Chacko E, Wood-Baker RW, Cates CJ. Influenza vaccine for patients with chronic obstructive pulmonary disease. Cochrane Database Syst Rev. 2006:CD002733

41. Wongsurakiat $P$, Lertakyamanee J, Maranetra KN, Jongriratanakul S, Sangkaew S. Economic evaluation of influenza vaccination in Thai chronic obstructive pulmonary disease patients. J Med Assoc Thai. 2003;86:497-508.

42. Nichol KL, Margolis KL, Wuorenma J, Von Sternberg T. The efficacy and cost effectiveness of vaccination against influenza among elderly persons living in the community. N Engl J Med. 1994;331:778-84.

43. Fiore AE, Shay DK, Broder K, Iskander JK, Uyeki TM, Mootrey G, Bresee JS, Cox NJ. Prevention and control of seasonal influenza with vaccines: recommendations of the Advisory Committee on Immunization Practices (ACIP), 2009. MMWR Recomm Rep. 2009;58:1-52.

44. Huang CL, Nguyen PA, Kuo PL, Iqbal U, Hsu YH, Jian WS. Influenza vaccination and reduction in risk of ischemic heart disease among chronic obstructive pulmonary elderly. Comput Methods Programs Biomed. 2013;111:507-11.

45. Santus P, Radovanovic D, Balzano G, Pecchiari M, Raccanelli R, Sarno N, Di Marco F, Jones PW, Carone M. Improvements in lung diffusion capacity following pulmonary rehabilitation in COPD with and without ventilation inhomogeneity. Respiration. 2016;92:295-307.

46. McCarthy B, Casey D, Devane D, Murphy K, Murphy E, Lacasse Y. Pulmonary rehabilitation for chronic obstructive pulmonary disease. Cochrane Database Syst Rev. 2015;2:CD003793.

47. Puhan MA, Gimeno-Santos E, Scharplatz M, Troosters T, Walters EH, Steurer J. Pulmonary rehabilitation following exacerbations of chronic obstructive pulmonary disease. Cochrane Database Syst Rev. 2011;CD005305.

48. van Ranst D, Stoop WA, Meijer JW, Otten HJ, van de Port IG. Reduction of exacerbation frequency in patients with COPD after participation in a comprehensive pulmonary rehabilitation program. Int J Chron Obstruct Pulmon Dis. 2014:9:1059-67.

49. Washko GR, Fan VS, Ramsey SD, Mohsenifar Z, Martinez F, Make BJ, Sciurba FC, Criner GJ, Minai O, Decamp MM, et al. The effect of lung volume reduction surgery on chronic obstructive pulmonary disease exacerbations. Am J Respir Crit Care Med. 2008;177:164-69.

50. Zanoria SJ, ZuWallack R. Directly measured physical activity as a predictor of hospitalizations in patients with chronic obstructive pulmonary disease. Chron Respir Dis. 2013:10:207-13.

51. Esteban C, Arostegui I, Aburto M, Moraza J, Quintana JM, Aizpiri S, Basualdo LV, Capelastegui A. Influence of changes in physical activity on frequency of hospitalization in chronic obstructive pulmonary disease. Respirology. 2014; 19:330-8.

52. Chawla H, Bulathsinghala C, Tejada JP, Wakefield D, ZuWallack R. Physical activity as a predictor of thirty-day hospital readmission after a discharge for a clinical exacerbation of chronic obstructive pulmonary disease. Ann Am Thorac Soc. 2014;11:1203-9.

53. Vogelmeier C, Hederer B, Glaab T, Schmidt H, Rutten-van Mölken MP, Beeh KM, Rabe KF, Fabbri LM. Tiotropium versus salmeterol for the prevention of exacerbations of COPD. N Engl J Med. 2011;364:1093-103.

54. Wedzicha JA, Calverley PM, Seemungal TA. Hagan G, Ansari Z, Stockley RA, INSPIRE investigators. The prevention of chronic obstructive pulmonary disease exacerbations by salmeterol/fluticasone propionate or tiotropium bromide. Am J Respir Crit Care Med. 2008;177:19-26.

55. Barnes PJ. Muscarinic receptor subtypes in airways. Life Sci. 1993;52:521-27.

56. Eglen RM, Hegde SS, Watson N. Muscarinic receptor subtypes and smooth muscle function. Pharmacol Rev. 1996:48:531-65.

57. O'Donnell DE, Fluge T, Gerken F, Hamilton A, Webb K, Aguilaniu B, Make B, Magnussen $\mathrm{H}$. Effects of tiotropium on lung hyperinflation, dyspnoea and exercise tolerance in COPD. Eur Respir J. 2004;23:832-40.

58. Beeh KM, Burgel PR, Franssen FM, Lopez-Campos JL, Loukides S, Hurst JR, Fležar M, Ulrik CS, Di Marco F, Stolz D, et al. How do dual long-acting bronchodilators prevent exacerbations of chronic obstructive pulmonary disease? Am J Respir Crit Care Med. 2016: doi: 10.1164/rccm.201609-201794Cl.

59. Meyer T, Reitmeir P, Brand P, Herpich C, Sommerer K, Schulze A, Scheuch G, Newman S. Effects of formoterol and tiotropium bromide on mucus clearance in patients with COPD. Respir Med. 2011;105:900-6. 
60. D'Urzo AD, Rennard SI, Kerwin EM, Mergel V, Leslbaum AR, Caracta CF. Efficacy and safety of fixed-dose combinations of aclidinium bromide/ formoterol fumarate: the 24-week, randomized, placebo-controlled AUGMENT COPD study. Respir Res. 2014;15:123.

61. Santus P, Buccellati C, Centanni S, Fumagalli F, Busatto P, Blasi F, Sala A. Bronchodilators modulate inflammation in chronic obstructive pulmonary disease subjects. Pharmacol Res. 2012;66:343-48.

62. Casaburi R, Mahler DA, Jones PW, Wanner A, San PG, ZuWallack RL, Menjoge SS, Serby CW, Witek Jr T. A long-term evaluation of once-daily inhaled tiotropium in chronic obstructive pulmonary disease. Eur Respir J. 2002;19:217-24.

63. Brusasco V, Hodder R, Miravitlles M, Korducki L, Towse L, Kesten S. Health outcomes following treatment for six months with once daily tiotropium compared with twice daily salmeterol in patients with COPD. Thorax. 2003;58:399-404.

64. Niewoehner DE, Rice K, Cote C, Paulson D, Cooper Jr JA, Korducki L, Cassino C, Kesten S. Prevention of exacerbations of chronic obstructive pulmonary disease with tiotropium, a once-daily inhaled anticholinergic bronchodilator: a randomized trial. Ann Intern Med. 2005;143:317-26.

65. Dusser D, Bravo ML, lacono P. The effect of tiotropium on exacerbations and airflow in patients with COPD. Eur Respir J. 2006;27:547-55.

66. Powrie DJ, Wilkinson TM, Donaldson GC, Jones P, Scrine K, Viel K, Kesten S, Wedzicha JA. Effect of tiotropium on sputum and serum inflammatory markers and exacerbations in COPD. Eur Respir J. 2007;30:472-78.

67. Tonnel AB, Perez T, Grosbois JM, Verkindre C, Bravo ML, Brun M. Effect of tiotropium on health-related quality of life as a primary efficacy endpoint in COPD. Int J Chron Obstruct Pulmon Dis. 2008;3:301-10.

68. Tashkin DP, Celli B, Senn S, Burkhart D, Kesten S, Menjoge S, Decramer M. A 4-year trial of tiotropium in chronic obstructive pulmonary disease. $\mathrm{N}$ Engl J Med. 2008:359:1543-54.

69. Bateman E, Singh D, Smith D, Disse B, Towse L, Massey D, Blatchford J, Pavia D, Hodder R. Efficacy and safety of tiotropium Respimat SMI in COPD in two 1-year randomized studies. Int J Chron Obstruct Pulmon Dis. 2010;5:197-208.

70. Bateman ED, Tashkin D, Siafakas N, Dahl R, Towse L, Massey D, Pavia D, Zhong NS. A one-year trial of tiotropium Respimat plus usual therapy in COPD patients. Respir Med. 2010;104:1460-72.

71. D'Urzo A, Ferguson GT, van Noord JA, Hirata K, Martin C, Horton R, Lu Y, Banerji D, Overend T. Efficacy and safety of once-daily NVA237 in patients with moderate-to-severe COPD: the GLOW1 trial. Respir Res. 2011;12:156.

72. Kerwin E, Hébert J, Gallagher N, Martin C, Overend T, Alagappan VK, Lu Y, Banerji D. Efficacy and safety of NVA237 versus placebo and tiotropium in patients with COPD: the GLOW2 study. Eur Respir J. 2012:40:1106-14.

73. Kerwin EM, D'Urzo AD, Gelb AF, Lakkis H, Garcia GE, Caracta CF. Efficacy and safety of a 12-week treatment with twice-daily aclidinium bromide in COPD patients (ACCORD COPD I). COPD. 2012;9:90-101.

74. Jones PW, Singh D, Bateman ED, Agusti A, Lamarca R, de Miquel G, Segarra R, Caracta C, Garcia GE. Efficacy and safety of twice-daily aclidinium bromide in COPD patients: the ATTAIN study. Eur Respir J. 2012;40:830-6.

75. Celli B, Crater G, Kilbride S, Mehta R, Tabberer M, Kalberg CJ, Church A. Once-daily umeclidinium/vilanterol 125/25 mcg in COPD: a randomized, controlled study. Chest. 2014;145:981-91.

76. Stockley RA, Chopra N, Rice L. Addition of salmeterol to existing treatment in patients with COPD: a 12 month study. Thorax. 2006;61:122-8.

77. Dahl R, Chung KF, Buhl R, Magnussen H, Nonikov V, Jack D, Bleasdale P, Owen R, Higgins M, Kramer B. Efficacy of a new once-daily long-acting inhaled $b_{2}$-agonist indacaterol versus twice-daily formoterol in COPD. Thorax. 2010;65:473-9.

78. Chapman KR, Rennard SI, Dogra A, Owen R, Lassen C, Kramer B, INDORSE study investigators. Long-term safety and efficacy of indacaterol, a longacting $\beta_{2}$-agonist, in subjects with COPD: a randomized, placebo-controlled study. Chest. 2011;140:68-75.

79. Donohue J, Fogarty C, Lötvall J, Mahler DA, Worth H, Yorgancioglu A, lqbal A, Swales J, Owen R, Higgins M, Kramer B; INHANCE Study Investigators, et al. Once-daily bronchodilators for chronic obstructive pulmonary disease: indacaterol versus tiotropium. Am J Respir Crit Care Med. 2010;182:155-62.

80. Decramer ML, Chapman KR, Dahl R, Frith P, Devouassoux G, Fritscher C, Cameron R, Shoaib M, Lawrence D, Young D, et al. Once-daily indacaterol versus tiotropium for patients with severe chronic obstructive pulmonary disease (INVIGORATE): a randomised, blinded, parallel-group study. Lancet Respir Med. 2013;1:524-33.

81. Cazzola M, Molimard M. The scientific rationale for combining long-acting $\beta$-agonists and muscarinic antagonists in COPD. Pulm Pharmacol Ther. 2010; 23:257-67.
82. Novartis. UTIBRON NEOHALER prescribing information. Revised October 2015. https://www.utibron.com/Utibron-Prescribing-Information.pdf. Accessed 5 June 2017.

83. Bateman ED, Chapman KR, Singh D, D'Urzo AD, Molins E, Leselbaum A, Gil EG. Aclidinium bromide and formoterol fumarate as a fixed-dose combination in COPD: pooled analysis of symptoms and exacerbations from two six-month, multicentre, randomised studies (ACLIFORM and AUGMENT). Respir Res. 2015;16:92.

84. Leidy NK, Wilcox TK, Jones PW, Murray L, Winnette R, Howard K, Petrillo J, Powers J, Sethi S. Development of the EXAcerbations of Chronic Obstructive Pulmonary Disease Tool (EXACT): a patient-reported outcome (PRO) measure. Value Health. 2010;13:965-75.

85. Decramer M, Anzueto A, Kerwin E, Kaelin T, Richard N, Crater G, Tabberer M, Harris S, Church A. Efficacy and safety of umeclidinium plus vilanterol versus tiotropium, vilanterol, or umeclidinium monotherapies over 24 weeks in patients with chronic obstructive pulmonary disease: results from two multicentre, blinded, randomised controlled trials. Lancet Respir Med. 2014;2:472-86.

86. ClinicalTrials.gov. NCT02296138. Comparing the Efficacy of Tiotropium + Olodaterol $(5 / 5 \mu \mathrm{g})$ Fixed Dose Combination (FDC) Over Tiotropium $5 \mu \mathrm{g}$ in Reducing Moderate to Severe Exacerbations in Patients With Severe to Very Severe Chronic Obstructive Pulmonary Disease. Updated 5 September 2016. https:/clinicaltrials.gov/ct2/show/NCT02296138?term = NCT02296138\&rank $=1$. Accessed 17 Jan 2017.

87. Calverley PM, Anderson JA. Celli B, Ferguson GT, Jenkins C, Jones PW, Yates JC, Vestbo J, investigators T. Salmeterol and fluticasone propionate and survival in chronic obstructive pulmonary disease. N Engl J Med. 2007;356:775-89.

88. Dransfield MT, Bourbeau J, Jones PW, Hanania NA, Mahler DA, Vestbo J, Wachtel A, Martinez FJ, Barnhart F, Sanford L, et al. Once-daily inhaled fluticasone furoate and vilanterol versus vilanterol only for prevention of exacerbations of COPD: two replicate double-blind, parallel-group, randomised controlled trials. Lancet Respir Med. 2013;1:210-23.

89. Martinez FJ, Vestbo J, Anderson JA, Brook RD, Celli BR, Cowans NJ, Crim C, Dransfield M, Kilbride S, Yates J, et al. Effect of fluticasone furoate and vilanterol on exacerbations of COPD in patients with moderate airflow obstruction. Am J Respir Crit Care Med. 2017;195:881-8.

90. Banerji D, Fedele M, Chen H. Once-daily dual bronchodilation with QVA149 reduces COPD exacerbations: results from the IGNITE program. Chest. 2014; 145(3_Meeting abstracts):403A. Abstract.

91. Vogelmeier C, Zhong N, Humphries MJ, Mezzi K, Fogel R, Bader G, Patalano F, Banerji D. Indacaterol/glycopyrronium in symptomatic patients with COPD (GOLD B and GOLD D) versus salmeterol/fluticasone: ILLUMINATE/LANTERN pooled analysis. Int J Chron Obstruct Pulmon Dis. 2016;11:3189-97.

92. Singh D, Worsley S, Zhu CQ, Hardaker L, Church A. Umeclidinium/vilanterol versus fluticasone propionate/salmeterol in COPD: a randomised trial. BMC Pulm Med. 2015;15:91

93. Singh D, Papi A, Corradi M, Pavlisova I, Montagna I, Francisco C, Cohuet G, Vezzoli S, Scuri M, Vestbo J. Single inhaler triple therapy versus inhaled corticosteroid plus long-acting $\beta 2$-agonist therapy for chronic obstructive pulmonary disease (TRILOGY): a double-blind, parallel group, randomised controlled trial. Lancet. 2016;388:963-73.

94. Vestbo J, Papi A, Corradi M, Blazhko V, Montagna I, Francisco C, Cohuet G, Vezzoli S, Scuri M, Singh D. Single inhaler extrafine triple therapy versus long-acting muscarinic antagonist therapy for chronic obstructive pulmonary disease (TRINITY): a double-blind, parallel group, randomised controlled trial. Lancet. 2017;389:1919-29.

95. Pascoe SJ, Lipson DA, Locantore N, Barnacle H, Brealey N, Mohindra R, Dransfield MT, Pavord I, Barnes N. A phase III randomised controlled trial of single-dose triple therapy in COPD: the IMPACT protocol. Eur Respir J. 2016; 48:320-30.

96. Poole P, Black PN, Cates CJ. Mucolytic agents for chronic bronchitis or chronic obstructive pulmonary disease. Cochrane Database Syst Rev. 2012:8:CD001287.

97. Criner GJ, Bourbeau J, Diekemper RL, Ouellette DR, Goodridge D, Hernandez P, Curren K, Balter MS, Bhutani M, Camp PG, et al. Prevention of acute exacerbations of COPD: American College of Chest Physicians and Canadian Thoracic Society Guideline. Chest. 2015;147:894-942.

98. Pela R, Calcagni AM, Subiaco S, Isidori P, Tubaldi A, Sanguinetti CM. $\mathrm{N}$-acetylcysteine reduces the exacerbation rate in patients with moderate to severe COPD. Respiration. 1999;66:495-500.

99. Zheng JP, Wen FQ, Bai CX, Wan HY, Kang J, Chen P, Yao WZ, Ma LJ, Li X, Raiteri $\mathrm{L}$, et al. Twice daily $\mathrm{N}$-acetylcysteine $600 \mathrm{mg}$ for exacerbations of 
chronic obstructive pulmonary disease (PANTHEON): a randomised, doubleblind placebo-controlled trial. Lancet Respir Med. 2014;2:187-94.

100. Decramer M, Rutten-van Molken M, Dekhuijzen PN, Troosters T, van Herwaarden C, Pellegrino R, van Schayck CP, Olivieri D, Del Donno M, De Backer W, et al. Effects of $\mathrm{N}$-acetylcysteine on outcomes in chronic obstructive pulmonary disease (Bronchitis Randomized on NAC Cost-Utility Study, BRONCUS): a randomised placebo-controlled trial. Lancet. 2005;365: 1552-60.

101. Cazzola M, Calzetta L, Page C, Jardim J, Chuchalin AG, Rogliani P, Gabriella MM. Influence of $\mathrm{N}$-acetylcysteine on chronic bronchitis or COPD exacerbations: a meta-analysis. Eur Respir Rev. 2015;24:451-61.

102. Tse HN, Raiteri L, Wong KY, Ng LY, Yee KS, Tseng CZ. Benefits of high-dose $\mathrm{N}$-acetylcysteine to exacerbation-prone patients with COPD. Chest. 2014;146:611-23.

103. Moretti M, Bottrighi P, Dallari R, Da Porto R, Dolcetti A, Grandi P, Garuti G, Guffanti E, Roversi P, De Gugliemo M, et al. The effect of long-term treatment with erdosteine on chronic obstructive pulmonary disease: the EQUALIFE Study. Drugs Exp Clin Res. 2004;30:143-52.

104. Moretti M, Fagnani S. Erdosteine reduces inflammation and time to first exacerbation postdischarge in hospitalized patients with AECOPD. Int J Chron Obstruct Pulmon Dis. 2015;10:2319-25.

105. Allegra L, Cordaro Cl, Grassi C. Prevention of acute exacerbations of chronic obstructive bronchitis with carbocysteine lysine salt monohydrate: a multicenter, double-blind, placebo-controlled trial. Respiration. 1996;63:174-80.

106. Zheng JP, Kang J, Huang SG, Chen P, Yao WZ, Yang L, Bai CX, Wang CZ, Wang C, Chen BY, et al. Effect of carbocisteine on acute exacerbation of chronic obstructive pulmonary disease (PEACE Study): a randomised placebo-controlled study. Lancet. 2008;371:2013-18.

107. Luo J, Wang K, Liu D, Liang BM, Liu CT. Can roflumilast, a phosphodiesterase-4 inhibitor, improve clinical outcomes in patients with moderate-to-severe chronic obstructive pulmonary disease? A meta-analysis Respir Res. 2016;17:18.

108. Martinez FJ, Calverley PM, Goehring UM, Brose M, Fabbri LM, Rabe KF. Effect of roflumilast on exacerbations in patients with severe chronic obstructive pulmonary disease uncontrolled by combination therapy (REACT): a multicentre randomised controlled trial. Lancet. 2015;385:857-66.

109. Martinez FJ, Rabe KF, Sethi S, Pizzichini E, Mclvor A, Anzueto A, Alagappan VK, Siddiqui S, Rekeda L, Miller CJ, et al. Effect of roflumilast and inhaled corticosteroid/long-acting $\beta 2$-agonist on chronic obstructive pulmonary disease exacerbations (RE 2 SPOND). A randomized clinical trial. Am J Respir Crit Care Med. 2016;194:559-67.

110. Electronic Medicines Compendium (EMC). DAXAS (roflumilast) 500 micrograms film-coated tablets. Summary of Product Characteristics (SmPC). Updated 1 March 2016. https://www.medicines.org.uk/emc/medicine/23416. Accessed 12 May 2017.

111. Uzun S, Djamin RS, Kluytmans JA, Mulder PG, van't Veer NE, Ermens AA, Pelle AJ, Hoogsteden HC, Aerts JG, van der Eerden MM. Azithromycin maintenance treatment in patients with frequent exacerbations of chronic obstructive pulmonary disease (COLUMBUS): a randomised, double-blind, placebo-controlled trial. Lancet Respir Med. 2014;2:361-8.

112. Albert RK, Connett J, Bailey WC, Casaburi R, Cooper Jr JA, Criner GJ, Curtis $J$, Dransfield MT, Han MK, Lazarus SC, et al. Azithromycin for prevention of exacerbations of COPD. N Engl J Med. 2011;365:689-98.

113. He ZY, Ou LM, Zhang JQ, Bai J, Liu GN, Li MH, Deng JM, MacNee W, Zhong $\mathrm{XN}$. Effect of 6 months of erythromycin treatment on inflammatory cells in induced sputum and exacerbations in chronic obstructive pulmonary disease. Respiration. 2010;80:445-52

114. Seemungal TA, Wilkinson TM, Hurst JR, Perera WR, Sapsford RJ, Wedzicha JA. Long-term erythromycin therapy is associated with decreased chronic obstructive pulmonary disease exacerbations. Am J Respir Crit Care Med. 2008;178:1139-47.

115. Alcázar Navarrete B, Casanova C, Miravitlles M, de Lucas P, Riesco JA, Rodríguez González-Moro JM, Working Group "Consensus document on the appropriate use of inhaled corticosteroids in C. "Correct use of inhaled corticosteroids in chronic obstructive pulmonary disease": a consensus document. Arch Bronconeumol. 2015:51:193-8.

116. Suissa $S$, Ernst $P$, Vandemheen $K L$, Aaron SD. Methodological issues in therapeutic trials of COPD. Eur Respir J. 2008;31:927-33.

117. Pascoe S, Locantore N, Dransfield MT, Barnes NC, Pavord ID. Blood eosinophil counts, exacerbations, and response to the addition of inhaled fluticasone furoate to vilanterol in patients with chronic obstructive pulmonary disease: a secondary analysis of data from two parallel randomised controlled trials. Lancet Respir Med. 2015;3:435-42.

118. Pavord ID, Lettis S, Locantore N, Pascoe S, Jones PW, Wedzicha JA, Barnes NC. Blood eosinophils and inhaled corticosteroid/long-acting $\beta 2$ agonist efficacy in COPD. Thorax. 2016;71:118-25.

119. Watz H, Tetzlaff K, Wouters EF, Kirsten A, Magnussen $H$, Rodriguez-Roisin $R$, Vogelmeier C, Fabbri LM, Chanez P, Dahl R, et al. Blood eosinophil count and exacerbations in severe chronic obstructive pulmonary disease after withdrawal of inhaled corticosteroids: a post-hoc analysis of the WISDOM trial. Lancet Respir Med. 2016;4:390-8.

120. Siddiqui SH, Pavord I, Barnes N, Lettis S, Guasconi A, Petruzzelli S. Blood eosinophils (EOS) are a biomarker of COPD exacerbation reduction with inhaled corticosteroids (ICS): an across-trials model-based approach. Eur Respir J. 2016:48:OA1763.

121. Calverley P, Tetzlaff K, Vogelmeier C, Fabbri L, Magnussen H, Wouters E, Mezzanotte W, Disse B, Finnigan H, Asijee GM, Hallmann C, Watz H. Evaluating blood eosinophils and exacerbation history to predict ICS response in COPD. Am J Respir Crit Care Med. 2017. doi:10.1164/rccm. 201612-2525LE. [Epub ahead of print].

122. Miravitlles M, D'Urzo A, Singh D, Koblizek V. Pharmacological strategies to reduce exacerbation risk in COPD: a narrative review. Respir Res. 2016;17:112.

123. Miravitlles M, Anzueto A. A new two-step algorithm for the treatment of COPD. Eur Respir J. 2017;49: doi:10.1183/13993003.02200-2016.

124. Cooper CB, Barjaktarevic I. A new algorithm for the management of COPD. Lancet Respir Med. 2015;3:266-8.

125. Chan CK, Maltais F, Sigouin C, Haddon JM, Ford GT. A randomized controlled trial to assess the efficacy of tiotropium in Canadian patients with chronic obstructive pulmonary disease. Can Respir J. 2007;14:465-72.

126. Abrahams R, Moroni-Zentgraf P, Ramsdell J, Schmidt H, Joseph E, Karpel J. Safety and efficacy of the once-daily anticholinergic BEA2180 compared with tiotropium in patients with COPD. Respir Med. 2013;107:854-62.

127. Aaron SD, Vandemheen KL, Fergusson D, Maltais F, Bourbeau J, Goldstein R, Balter M, O'Donnell D, Mclvor A, Sharma S, et al. Tiotropium in combination with placebo, salmeterol, or fluticasone-salmeterol for treatment of chronic obstructive pulmonary disease: a randomized trial. Ann Intern Med. 2007; 146:545-55

128. Maleki-Yazdi MR, Kaelin T, Richard N, Zvarich M, Church A. Efficacy and safety of umeclidinium/vilanterol 62.5/25 mcg and tiotropium $18 \mathrm{mcg}$ in chronic obstructive pulmonary disease: Results of a 24-week, randomized, controlled trial. Respir Med. 2014;108:1752-60.

129. Ohar JA, Crater GD, Emmett A, Ferro TJ, Morris AN, Raphiou I, Sriram PS, Dransfield MT. Fluticasone propionate/salmeterol 250/50 $\mu \mathrm{g}$ versus salmeterol $50 \mu \mathrm{g}$ after chronic obstructive pulmonary disease exacerbation. Respir Res. 2014;15:105.

130. Calverley PM, Kuna P, Monsó E, Costantini M, Petruzzelli S, Sergio F, Varoli G, Papi A, Brusasco V. Beclomethasone/formoterol in the management of COPD: a randomised controlled trial. Respir Med. 2010;104:1858-68.

131. Bateman ED, Vogelmeier C, Chen H, Banerji D. Comparison of COPD exacerbations with once-daily QVA149 versus twice-daily salmeterol/ fluticasone combination: the ILLUMINATE study. Chest. 2014;145(3_Meeting abstracts):409A. Abstract.

132. Vogelmeier C, Paggiaro PL, Dorca J, Sliwinski P, Mallet M, Kirsten A-M, Seoane B, Segarra RM, Leselbaum A, Gil EG. The efficacy and safety of aclidinium/formoterol fixed-dose combination compared with salmeterol/ fluticasone in patients with COPD: results from a phase III study. Am J Respir Crit Care Med. 2015;191(1):A3974. Poster P3611.

133. Beeh KM, Derom E, Echave-Sustaeta J, Gronke L, Hamilton A, Zhai D, Bjermer $L$. The lung function profile of once-daily tiotropium and olodaterol via Respimat is superior to that of twice-daily salmeterol and fluticasone propionate via Accuhaler (ENERGITO ${ }^{\circ}$ study). Int J Chron Obstruct Pulmon Dis. 2016;11:193-205.

134. Troosters T, Sciurba FC, Decramer M, Siafakas NM, Klioze SS, Sutradhar SC, Weisman IM, Yunis C. Tiotropium in patients with moderate COPD naive to maintenance therapy: a randomised placebo-controlled trial. NPJ Prim Care Respir Med. 2014;24:14003. 